\title{
LA RELIGIÓN ROMANA EN MENORCA: APROXIMACIÓN DESDE LAS FUENTES ICONOGRÁFICAS
}

\author{
ROMAN RELIGION IN MENORCA: APPROACH THROUGH THE ICONOGRAPHIC SOURCES
}

\section{A. SANTIAGO MORENO PÉREZ}

\section{INTRODUCCIÓN}

En el periodo de tiempo comprendido entre el final de la Segunda Guerra Púnica (218-202 adne), acontecimiento que marca el inicio de las relaciones isleñas con Roma ${ }^{2}$ y los edictos de Milán (313) y Tesalónica (380), momento en el que el cristianismo se convierte en religión del estado en detrimento de los antiguos cultos paganos, la documentación iconográfica de utilidad para el análisis de la incidencia de la religión y creencias romanas en la isla se ha conservado exclusivamente en soportes plásticos.

Entre las representaciones escultóricas en distintos formatos y soportes materiales destaca tanto en Mallorca como en Menorca la especial abundancia de pequeñas esculturas en soportes broncíneos ya desde comienzos del periodo postalayótico y que en época histórica constituyen un importante capítulo para el estudio de los bronces romanos de la Hispania Citerior (Rodá, 1990, 71-73). Sin embargo, la relevancia del material figurado protohistórico de Baleares ha centrado la mayor parte de los estudios, precisando la documentación romana una clasificación y revisión general. Para el caso de los materiales menorquines, destaca el trabajo de recopilación y estudio de M. Orfila (1982-83) donde se clasificaron un total de 38 piezas encuadradas cronológicamente entre el s. VI a.n.e. y la época tardo romana. No obstante, la inclusión de abundante y entonces inédito material protohistórico, supuso únicamente la reunión de 17 piezas del periodo romano, frente a los 26 ejemplares que se han podido recopilar en el presente

1. Grupo de investigación HUM 296, Junta de Andalucía. Doctorando del Departamento de Prehistoria y Arqueología de la Universidad de Granada.

2. Tanto a nivel comercial (De Nicolás, 1983, 225-227, 231; Orfila, 1995, 220-221; 2008, 13), como militar, con la incorporación de los auxilia baleáricos en el ejército romano (De Miguel, 2002, 531). Según se indicará en la parte del texto correspondiente, los documentos iconográficos romanos más antiguos se fechan en los ss. II-I adne en la isla. estudio (véase catálogo anexo, con bibliografía, con localización de muestras en Fig. 10), que en las fechas de realización del mencionado trabajo estaban repartidas en distintas colecciones privadas de complicado acceso.

La mayor parte de los bronces recopilados llegaron a la isla a través de las redes comerciales, destacando la identificación de producciones galas y de Italia septentrional. Casi todos están realizados por el método de fundición plena a la cera perdida, documentada en diversos talleres broncistas de época alto imperial, como por ejemplo en Galia (Montandon, 1997) y del norte de Italia (Rousel, 1979), en los que priman los factores de agilización y reducción de costes de producción, sobre todo mediante aleaciones con aumento de metales blandos como el plomo o el zinc (Sborgi, 1995, 45-46). Los factores aludidos responden a una creciente demanda de este tipo objetos a partir de época imperial, los cuales presentan un variado rango de calidades y oscilaciones del formato que a su vez facilitó su inserción en distintos estratos sociales, constituyendo una de las herramientas de penetración de ideas mítico-religiosas romanas en los ámbitos provinciales.

\section{LAS IMÁGENES EN ÉPOCA TARDO REPU- BLICANA}

Con anterioridad a los inicios del periodo julio claudio no existen documentos arqueológicos relacionados con la religión oficial o de los efectivos militares instalados en la isla a partir de la conquista de Baliares en 123 a.n.e. (Orfila, 2008). De hecho, el panorama iconográfico desde finales del s. III al I a.n.e. inclusive se caracteriza por una continuidad de las manifestaciones propias del ámbito cultural talayótico, así como las primeras importaciones de material figurado romano, probablemente como elementos de prestigio, siguiendo una pauta bien constatada en la isla desde inicios del periodo postalayótico, que explica en parte la especial abundancia de bronces de distinta procedencia al menos desde el s. V a.n.e. (Orfila, 1982-83). 

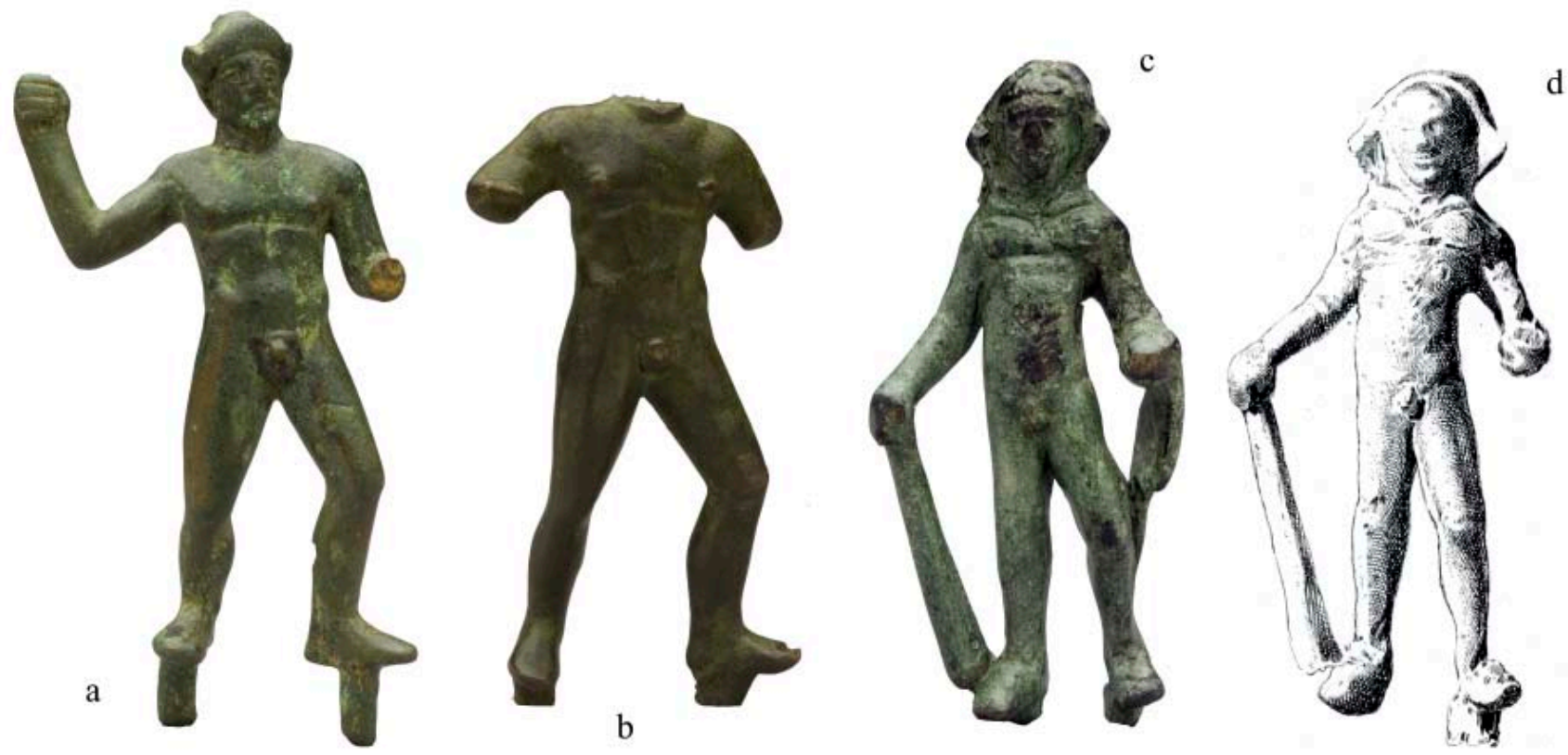

Figura 1: a) Binitram, HSA; b) procedencia desconocida, HSA; c) Calle Cos, Mahón, HSA; d) So n'Olivaret, Ciutadella, paradero desconocido (Fuentes: a-c, HSA; d, Orfila, 1982-83).

A las primeras se adscriben imágenes de temática zoomorfa, principalmente tauromorfa, las cuales representan un importante capítulo de la iconografía postalayótica, posiblemente vinculadas a las clases dominantes como símbolos de su poder y prestigio (Guerrero, 1994, 173; Gornés, 1997), y cuya continuidad en la etapa de dominio romano viene indicada por el contexto del exvoto de bronce con representación de un toro del recinto de la Taula de Torralba d'en Sarlot, complejo que presenta un uso cultual fechado por datación radiocarbónica desde finales del s. III a.n.e. al s. II d.n.e. (Fernández Miranda, 1976, 18; 1981). Una situación de continuidad similar se plantea para las estatuillas de guerreros desnudos, denominados en la historiografía reciente divinidades bélicas, que representan una de las facetas más destacadas de la iconografía postalayótica, asociadas a la exaltación de la masculinidad y el belicismo. Tales estatuillas, generalmente localizadas en complejos de uso colectivo, parecen consolidarse en los ss. IV-III a.n.e. (Llompart, 1960, 109; Orfila, 1982-83, 139-140; Gual, 1993, 41), y presentan una pervivencia al menos hasta finales del s. II a.n.e., constatada en Mallorca por el material cerámico de importación asociado a los ejemplares de Son Favar y Sa Punta en Son Carrió (en torno al 100 a.n.e.), y a través de su estudio iconográfico-estilístico, que delata su factura local y tardía, con elementos eclécticos suficientemente diferenciadores de las piezas del ámbito greco-itálico o púnico (Blech y Marzoli, 1991). La falta absoluta de una mínima contextualización arqueológica para las estatuillas menorquinas de este tipo impide precisar por estos medios su proyección cronológica a estas fechas, aunque las propiedades técnico-estilísticas de tres ejemplares, dos de ellos prácticamente idénticos conservados en la Hispanic Society of America $(=\mathrm{HSA})^{3}$ (Fig. 1 a-b) y otro muy fragmentario del poblado de Binicalaf que sigue pautas muy similares (Llompart 1960, 105, lám. 5, 2; Orfila 1982-83, 118, fig. 12), son comparables con la producción tardía de Mallorca, posibilitando una datación genérica entre los ss. III-I a.n.e..

En cuanto al material iconográfico propiamente romano deben distinguirse en primer lugar algunas piezas figuradas importadas, que se insertan en el contexto comercial de progresiva incidencia de productos itálicos a partir de la Segunda Guerra Púnica. Entre ellas una entalladura sobre ágata perteneciente probablemente a un anillo, con representación de un joven sátiro, fechada entre los ss. II-I a.n.e. ( $\left.\mathrm{n}^{\mathrm{o}} 12\right)$, procedente del poblado de Talatí de Dalt, cuya suntuosidad y excelente calidad implican principalmente su empleo como elemento de prestigio y el gusto por las temáticas mitológicas greco-romanas. Tales temáticas tuvieron una proyección en época imperial documentada en este mismo poblado a través del aplique broncíneo con máscara de Sátiro-Somnus $\left(\mathrm{n}^{\circ} 13\right)$.

Otra pieza de importación, probablemente fabricada en un taller de Italia, sería la estatuilla de bronce de joven $\left(\mathrm{n}^{\mathrm{o}} 21\right.$, Fig. 2$)$ procedente de Torre Vella d'en Lozano. El joven está ataviado con un himation que aparece en la iconografía helenística hacia el s.

3. Uno de ellos procedente del poblado de Biniatram (se cita específicamente «del talayot)») que Llompart fechaba en época imperial (Llompart, 1960, 104; Orfila, 1982-83, 118-119), otro de localización imprecisa (Llompart, 1960, 104; 1970, 233; García y Bellido, 1993, 266, lám. 294-6). 

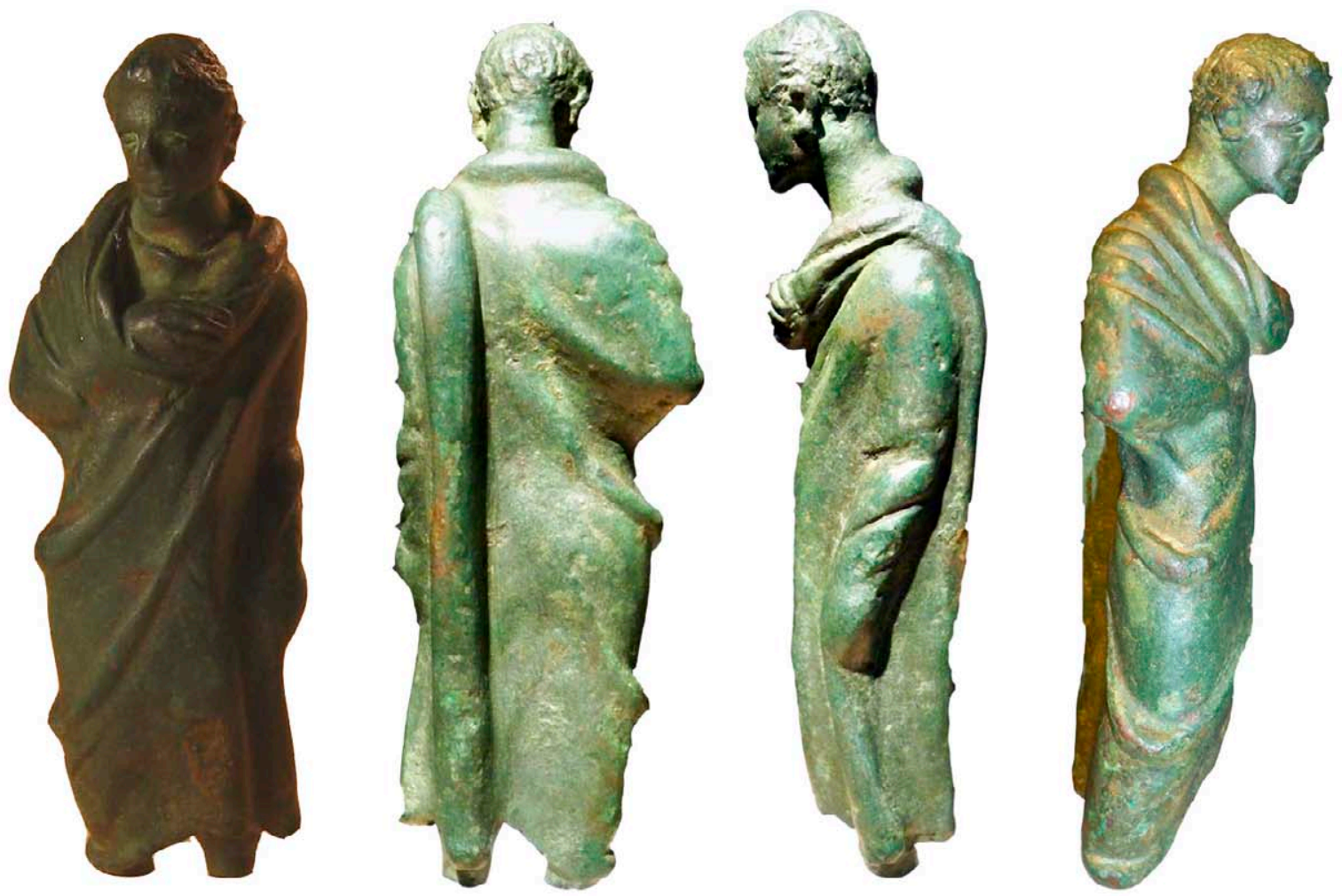

Figura 2: Joven palliatus de Torre Vella de'n Lozano.

III a.n.e. y que pasa en Roma a conformar un tipo de toga de época tardo republicana, denominada de tipo pallium (Goette, 1990, 24-27), de gran desarrollo en la estatuaria de gran formato ${ }^{4}$, y que se va a insertar en los modelos votivos de jóvenes togados de bronce.

Tales estatuillas de jóvenes con manto presentan una tradición arraigada en el ámbito itálico y etrusco al menos desde el s. IV a.n.e., provistos en ocasiones de dedicatoria epigráfica sobre la propia pieza y depositados en distintos santuarios (Galestin, 1987, 100 ss.), detectándose dedicaciones impresas en las estatuillas ya en latín coincidiendo con las últimas producciones de tipo etrusco y el desarrollo de los palliati (Cristofani, 1985, nº 66; Galestin, 1987, 110-114), al modo por ejemplo de piezas similares a la menorquina procedentes del santuario de Pozzarello (Bolsena) fechadas en el s. II a.n.e. ${ }^{5}$. Ese tipo de estatuillas se relacionan en la historiografía con la festividad de Liberalia, ceremonia de paso a la edad adulta a partir de la cual se adquieren los derechos de la ciudadanía y la toga viril (Ovidio, fasti 3, 771), si bien el hallazgo de la pieza menorquina en un poblado talayótico, y su cronología temprana plantean su funcionalidad como objeto de prestigio, posiblemente desprovisto del carácter cultural para el que fue fundida.

4. También en la estatuaria tardo republicana de Hispania en piedra (Noguera, 2003).

5. Tamburini, P. en AAVV, 2007, 218-219, nº 333-336.
Recientemente se ha recuperado una gema incisa con representación de Hércules, procedente del denominado recinto Carthailac, una casa postalayótica del poblado de Torre d'en Gaumes, con un nivel de uso cerrado en el s. II a.n.e. (Sintés e Isbert, 2008, 257-258). Se trata en este caso de la representación más antigua del mítico heroe griego constatada en la isla, cuyo origen de producción sería en principio helenístico-romana ${ }^{6}$.

\section{DIVINIDADES CON ATRIBUCIONES BÉLICAS}

A diferencia de las dos primeras piezas importadas en época tardo republicana aludidas atrás, inicialmente valoradas como objetos de prestigio, las imágenes de Hércules presentan una continuidad en tiempos romanos a traves de dos estatuillas de bronce del dios $\left(\mathrm{n}^{\circ} 5\right.$ a-b, Fig. $1 \mathrm{c}-\mathrm{d}$ ), una de ellas procedente de la calle Cos de Mahón, conservada en la HSA, y otra, actualmente en paradero desconocido procedente de Sant Antoni, vulgo de So n'Olivaret (Ciutadella), estudiada por M. Orfila (1982-83, 123-124, fig. 19). Ambas piezas

6. No se ha podido estudiar la pieza original, pero su morfología y características generales podrían equipararse de modo preliminar a las producciones itálicas localizadas en importantes centros productores de Campania, Roma, Aquileia, y otros puntos del norte de Italia, que arrancan en el s. III a.n.e. (Sena y Facchini, 1985, 11-15). 

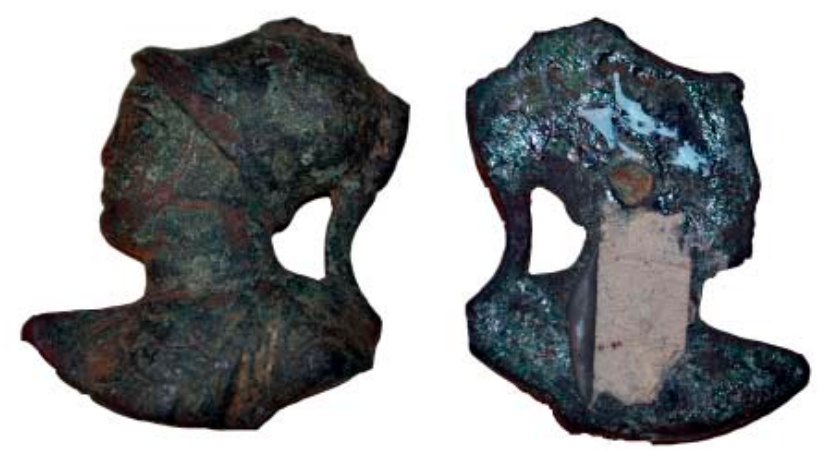

Figura 3: Aplique con busto de Minerva de Torre Trençada.

presentan un carácter iconográfico un tanto ecléctico, próximo a modelos romanos como el denominado tipo Montpellier o el Capitolino (Palagia, 1988, 786-787), de rasgos estilísticos próximos a piezas de época tardo republicana, o primera mitad del s. I d.n.e. ${ }^{7}$ Los caracteres provinciales se acentúan con la presencia de vástagos de fijación a plinto o pedestal en la base de los pies, un procedimiento técnico poco frecuente en los bronces romanos de pequeño formato, constatado en la estatuaria metálica postalayótica, incluyendo los ejemplares menorquines antes señalados (Fig. $1 \mathrm{a}-\mathrm{b}, \mathrm{y}$ el toro de Torralba). Tales elementos plantean la posibilidad del empleo de estas estatuillas como exvotos en espacios colectivos, ensamblados a pedestales pétreos al modo de la escultura de équido cuyas patas se documentaron in situ en el interior del recinto de Taula de Torralba d'en Salot (Fernández Miranda, 1981), o pedestales de tipo tardo helenísticos donde se ensamblaba al menos una de las estatuillas de guerreros de Son Favar, en Mallorca (Gual, 1993, 38-39). La evidente similitud de ambas piezas, distinguidas únicamente por la ausencia de la clámide enrollada al brazo del ejemplar del término de Ciutadella, y la presencia de los vástagos, tan recurridos en la estatuaria postalayótica, planean un mismo origen de producción, posiblemente balear.

El caso de Hércules, divinidad relacionada con la fuerza y de cierta importancia en el ejército romano ${ }^{8}$, puede ser ilustrativo de la confluencia, o la existencia de puntos de contacto, entre los cultos militares romanos y los postalayóticos vinculados a la exaltación del belicismo representados por la serie de guerreros de bronce antes aludida (Orfila 1995, 261; Amengual y Orfila, 2007, 224). Estas imágenes reflejan la

7. Resulta útil la comparación con una estatuilla de Hércules de características estilísticas próximas a los bronces menorquines, perteneciente a un larario de Pompeya que muestra acentuados rasgos itálicos diferenciados claramente del resto de imágenes del larario (Adamo-Muscettola, 1984, 17, fig. 10-14).

8. A Hércules se refiere la dedicación militar de edificios sacros en la proximidad de los campamentos, como ocurre en Petavonium (Moreno de Pablos, 2001, 131-142), o en la presencia de sus imágenes escultóricas, caso del campamento de Kögen (Jonson, 1983, 110-113, nota 41). importancia de la guerra en la sociedad local, parte de cuya población se encuentra integrada como tropas auxiliares en los ejércitos púnicos desde finales del s. V a.n.e. y romanos a partir de la Segunda Guerra Púnica, lo que pudo fomentar cierta familiaridad con los cultos castrenses de Roma que se afianzaría con la presencia de tropas en la isla a partir de la conquista del 123 a.n.e..

Sobre la importancia del belicismo y su proyección en la época romana son también interesantes los testimonios sobre el culto a Minerva. Las estatuillas de Atenea Promachos están presentes entre las primeras importaciones de material figurado broncíneo del ámbito talayótico, con dos piezas en Mallorca, y una de Menorca fechada en el s. VI a.n.e. (Orfila, 1982$83,109-112)$, lo que ha suscitado la hipótesis de una asimilación o sincretismo por la población local de la divinidad griega (Llompart, 1970, 240; Orfila, 1995, 261), y cuyo esquema iconográfico remite claramente a sus atribuciones bélicas y presenta, además, importantes paralelismos con la iconografía de tipo amenazante de los guerreros baleáricos. Las estatuillas de época romana de Minerva son también relativamente abundantes, dos de Mallorca (Llompart, 1970, 240; Gual, 1993, $\mathrm{n}^{\circ}$ 94, y 95), y otras dos de Menorca, una de ellas de Santa Creu $\left(\mathrm{n}^{\circ} 10\right)$, y un aplique con busto de la diosa del poblado de Torre Trençada $\left(\mathrm{n}^{\mathrm{o}} 11\right.$, Fig. 3), de rasgos estilísticos propios de un periodo ya avanzado, probablemente finales del s. III d.n.e.

La pieza se asocia a su aplicación a elementos no domésticos, ya que está realizada en una placa de escasísimo relieve, bien distinto a los habituales bustos ornamentales con representación de la diosa con cabeza exenta, según unas características constatadas en apliques figurados de carros con temáticas variadas, incluyendo divinidades (Boube-Picot, 1975, 215, n $336 ; 1980,341, \mathrm{n}^{\circ} 600$, pl. 119-120).

$\mathrm{Al}$ margen de los cultos cívicos relativos a la diosa, constatados en el templo Capitolino del Foro de Pollentia, estos documentos del ámbito rural pueden estar reflejando la importancia de divinidades con atribuciones bélicas en Menorca, y en concreto la continuidad de las imágenes de Atenea/Minerva, divinidad que formaba parte de los cultos militares romanos a la que se dedica la importante festividad de Quinquatria, del 19 al 23 de marzo (Fink et alii, 1940, 94-99), que culminaban con el tubilustrium, importante ritual de purificación de las armas de la milicia ${ }^{9}$. No obstante, la documentación actualmente disponible es insuficiente para confirmar una continuidad o sincretismo de este tipo, sobre todo teniendo en cuenta las amplias esferas de poder de la diosa, y la cronología tardía de la pieza $\mathrm{n}^{\mathrm{o}} 11$.

9. Estatuillas de Minerva se han documentado en campamentos militares imperiales, como sería el caso de un bronce del asentamiento militar de A Cidadela, Galicia (Costa, 2011, 759). 
Una situación similar a la anterior queda planteada en el caso de Júpiter, representado por dos estatuillas broncíneas, una de ellas procedente del poblado de Torre Trençada $\left(\mathrm{n}^{\circ} 6\right)$, y otra de las inmediaciones del de Bellaventura, en las inmediaciones del anterior $\left(\mathrm{n}^{\mathrm{o}} 7\right)$. En ambos casos se trata de piezas fechadas en época imperial avanzada, de nuevo procedentes del ámbito rural, y en ambos casos imágenes de gran difusión geográfica. En concreto la de Torre Trençada, de la segunda mitad del s. II o comienzos del III d.n.e., se adscribe en sus elementos básicos al tipo tonante, imagen atribuida a un original griego de Leochares (Plinio, Nat. His. 34, 79) instalada en el templo dedicado por Augusto en el año 22 a.n.e. en el Capitolio romano (Donnay, 1984). Por su parte la de Bellaventura, se fecha entre finales del s. I-s. II d.n.e., perteneciente al tipo Majesté, que se remonta a la imaginería religiosa griega del s. V a.n.e., cuyas pequeñas reproducciones en bronce de épocas alto y medio imperial conocieron una importante expansión en Europa, especialmente abundantes en Galia (Boucher, 1976, 84-86, carte XI). De hecho, el tratamiento particular de los mechones centrales partidos en la frente y el tipo de vaciado de la pupila se han detectado en talleres provinciales galo romanos como el de Schwarzenaker (Kolling, 1967, 30-34, pl. 27-39; Boucher, 1974, 155), planteándose su posible origen de producción en estos territorios.

Pese a que se trata de una divinidad con importantes atribuciones bélicas en Roma, donde se le venera como divinidad suprema de los ejércitos y a cuyo culto se asocian las enseñas militares, aquila, signa y vexila (Helgeland, 1978, 1475-76), y presenta ciertos paralelismos iconográficos con el guerrero baleárico desnudo y provisto de lanza, ante la falta de evidencias complementarias los documentos menorquines pueden ilustrar también la difusión en la sociedad civil de una divinidad de amplias atribuciones, y que en el ámbito rural mallorquín está constatado desde comienzos de época imperial, a través de las ofrendas que se le destinaron en el santuario de So n'Oms (Pena, 2005).

\section{LAS IMÁGENES DEL PERIODO PRE MUNICI- PAL, ÉPOCA JULIO CLAUDIA}

Entre la conquista militar del 123 a.n.e. y la promoción municipal de sus ciudades en 73-74 d.n.e., la incidencia cultural romana en Menorca responde a parámetros sensiblemente diferentes a los de la isla mayor, donde las primeras fundaciones urbanas del archipiélago, datadas por los niveles de Pollentia y Palma en los años 70-60 a.n.e. (Orfila et al., 2006), incluyen importantes infraestructuras destinadas a la religión oficial-cívica, como el templo de culto a la Triada Capitolina protectora del estado en el Foro de Pollentia (Zucca, 1998, 199; Orfila et alii, 1999), que implica a su vez el concurso de un ceremonial y sacerdocios competentes (Ruggiero, 1997, 20-21). En este sentido, el control de Menorca durante este periodo pre municipal se llevaría a cabo desde determinados asentamientos costeros postalayóticos como Iamo y Mago, a los que se dotaría de elementos físicos y administrativos de carácter militar ${ }^{10}$, confirmados por determinadas fuentes literarias en los que ambos figuran citados como castella (P. Mela, Chor. 2, 124), así como por asentamientos militares de nueva planta evidenciados por el campamento romano republicano de Sa Nitja (Contreras et alii., 2006).

Desde el punto de vista religioso, la ejecución en el ejército de ciertas actividades cultuales corresponde a individuos que forman parte de las tropas acuarteladas, provistos de determinados $\operatorname{cargos}^{11}$, mientras la autoridad civil y religiosa recae en este tipo de asentamientos en el tribuno o militar de mayor rango (Le Bohec, 1994, 53). Otras particularidades del ceremonial religioso militar respecto al civil residen en que a diferencia de colonias o municipios donde los calendarios religiosos oficiales se adaptan en ciertos aspectos a las circunstancias locales, los cultos llevados a cabo en los acuartelamientos, según la documentación proporcionada por el calendario militar conocido como Feriale Duranum $^{12}$, vienen prescritos por el estado y contienen un ceremonial muy ligado al de la religión oficial, ya que actúa como unificador religioso de las milicias y articulador de las creencias entre estado y ejercito. En este tipo de calendario quedan reflejados, junto a festividades propias del calendario civil, cultos estrictamente militares, entre los que destacan la importancia del culto a los signa o estandartes, y de las ceremonias relacionadas con el sacramentum militar y divinidades o abstracciones militares, todo lo cual contribuye a exaltar el espíritu castrense y la fidelidad a Roma (Helgeland, 1978).

Los primeros documentos relativos a los cultos del ejército romano en Menorca corresponden a comienzos de época julio claudia, resultando el más conocido e importante el retrato broncíneo de Tiberio, asociado a partir de los estudios de W. Trillmich (1990, 41-44) a una estatua del emperador, seguramente con atuendo militar, emplazada en el Castellum de Mago durante su gobierno, entre el 14 y el 37 d.n.e.. Tales aspectos ideológicos tuvieron un acusado reflejo en los cultos

10. Mago se va a dotar en época tardo republicana de un nuevo recinto amurallado superpuesto a un posible cercado talayótico anterior (Rita y Plantalamor, 1988; Orfila, 1995, 233; Rita, 2007, 121-122).

11. Tales como los haruspex, encargado de las consultas adivinatorias, victimarius y ad hostias, destinados al sacrificio de animales.

12. El papiro conocido como Feriale Duranum, hallado en Dura Europos (Siria), es un documento oficial, trasmitido desde Roma, que pertenecía a los archivos de la guarnición romana asentada allí, la Cohors XX Palmyrenorum millaria equitata, fechado en época del emperador Alejandro Severo, 225-227 dne. El documento conserva la mayor parte del calendario festivo religioso impuesto a la tropa (Fink et alii, 1940; Helgeland, 1978, 1481-84). 

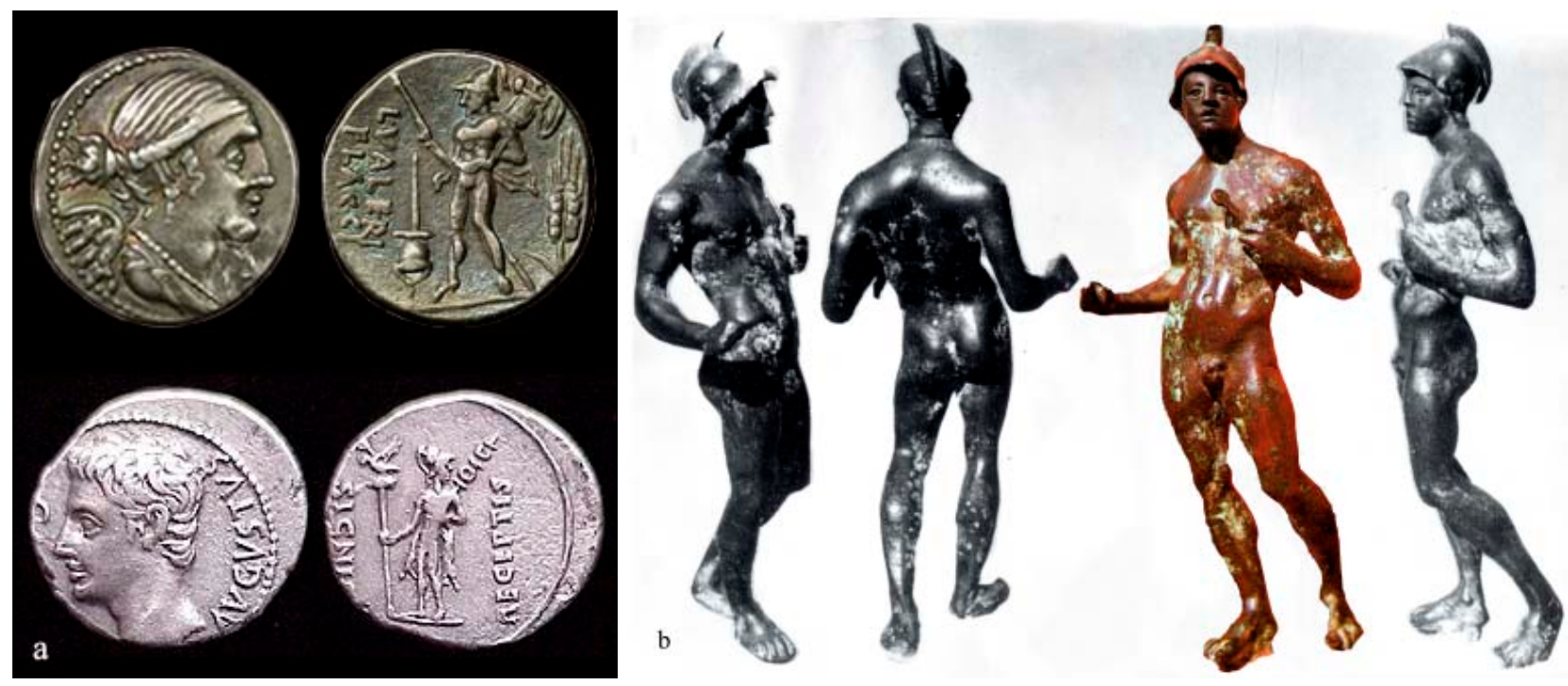

Figura 4: a) Parte superior: emisión de Roma 108-107 a.n.e. con la leyenda VALERI FLACCI; parte inferior: emisión augustea, probablemente hispana, con leyenda SIGNIS RECEPTIS. (Fuente: Internet); b) Estatuilla de Marte de Pujol el Antic de Cavallería (Fuente: Orfila, 1982-83).

militares, en particular centralizadas por la figura omnipotente del emperador, jefe supremo de los ejércitos, del estado, y sumo sacerdote, a quien las unidades militares juraban fidelidad en la importante ceremonia del sacramentum (Helgeland, 1978, 1478-80; Fishwick, 1991, 596). De hecho, de los 49 días festivos del calendario de Dura Europos, las celebraciones que implican dedicaciones bien al emperador reinante, a los divi (emperadores divinizados), o a miembros de la familia imperial, ascienden a 31 (Helgeland, 1978, 1481-1486; Campbell, 1994, 127 ss.). La imagen del emperador se convierte de este modo en un objeto de culto presente en los ejércitos tanto en las imagines de los estandartes, como por su destacada presencia en los principia o cuarteles generales de los campamentos, donde existía un sacellum en el que era frecuente su estatua entre las enseñas del destacamento (Domaszewski 1972, 96 ss; Helgeland 1978, 1473-1478), constituyendo uno de los más importantes objetos sacralizados por la milicia ${ }^{13}$.

En relación al ámbito de los cultos bélicos se encuentra la estatua del dios Marte procedente del poblado talayótico de Pujol el Antic de Cavallería ( $\mathrm{n}^{\circ} 8$, Fig. 4b), fechada por criterios estilísticos en la primera mitad del s. I d.n.e. (Llompart 1960, 105-106), seguramente en época augustea o tiberiana. Esta iconografía del dios aparece en Roma en las acuñaciones de L. Valerio Flaco en 108-107 a.n.e., donde se aprecia ya el característico dinamismo iconográfico de la pieza menorquina y su asociación a la victoria tanto por los trofeos militares que porta (tropaiophoros), un tipo de

13. La posición canónica inter signa de las estatuas en estas capillas castrenses viene también indicada en los textos de Tácito (Hist. 1, 36 y 1,35), y confirmada a través de numerosos hallazgos escultóricos y numismáticos. atributos que portaría también la estatua de Menorca, como por la presencia del busto de Victoria en el anverso (Fig. 4a).

Pero será en época augustea cuando esta iconografía encuentra amplia difusión como soporte iconográfico-propagandístico de la restauración de la virtus romana tras la campaña contra los partos en la que se liberan los cautivos y se recuperan los signa militaria arrebatados a las legiones en los años 53, 40 y 36 a.n.e.. Este evento, parte fundamental del discurso triunfalista de la política de Augusto, se reflejó en la acuñación de un nuevo numerario ${ }^{14}$, donde figura el joven dios, bajo este mismo tipo iconográfico, portando las enseñas aludidas (Fig. 4a). En variantes contemporáneas de estas emisiones es frecuente también idéntica representación del dios en el interior de un aedes y con la leyenda Mars Vltor, en referencia a la edificación sacra tradicionalmente interpretada como el templo dedicado al dios en el 19 a.n.e. en el Capitolio de Roma, precisamente para conmemorar el hecho y custodiar los estandartes (Gros, 1976, 97; Cassola, 1981, 99-118). A la oficialidad de esta iconografía se une la excelente calidad y formato de la pieza, un bronce de $20 \mathrm{~cm}$ de altura que destaca notablemente en la serie iconográfica a la que se adscribe ${ }^{15}$, algunos de cuyos ejemplares fueron asociados por Domaszewski a campamentos militares (1972, 34; Simon, 1984, 511). Estas características indican la excepcionalidad de la pieza, y su posible empleo en el ámbito oficial, quizás como señaló M. Orfila $(1995,241)$ en relación

14. Emisiones principalmente localizadas en Ephesos e Hispania, para estas últimas: Domínguez y Aguilera, 2009.

15. La pieza se adscribe al tipo Tänzer, «danza», conocido únicamente a través de piezas de pequeño formato (Simon, 1984, 511). 
a la civitas de Sanicera citada por Plinio ${ }^{16}$, no lejos del hallazgo, si bien su localización casual en un poblado talayótico (no excavado), y su parentesco iconográfico con los guerreros desnudos baleáricos plantea importantes dudas sobre su uso colectivo (¿sincretismo?) o privado.

\section{LOS CULTOS CÍVICOS}

A partir del edicto de latinidad concedido a las ciudades hispanas en época flavia (73/74 d.n.e.), que supuso en Menorca la promoción municipal de los enclaves portuarios de Iamo y Mago (Zucca, 1998, 155-158; Orfila y Riera, 2004; García Riaza, 2005, 96), los cultos cívicos practicados en los municipia menorquines parecen centrarse en aspectos políticos de veneración de Roma y sus emperadores, según se desprende de la documentación epigráfica con menciones de sacerdocios del culto imperial (Zucca, 1998, 200; García Riaza y Sánchez León, 2000, 168-170), así como de la presencia de imágenes públicas de las dinastías imperiales que debieron emplazarse en los centros ceremoniales, atestiguadas por la perdida estatua dedicada en Mago entorno al 214 d.n.e. al emperador Carracalla, conocida a través de su pedestal (CIBal, 120; Zucca, 1998, n 40).

Tales cultos tuvieron una proyección en el ámbito rural, como evidencia la dedicación sobre placa epigráfica de arenisca hallada en las inmediaciones de la Taula de Trepuco, realizada por el liberto Scrobonius Pax, que desempeñó el cargo de magíster lar(um) aug(ustalium) (CIBal, 127; Zucca, 1998, 200; García Riaza y Sánchez León, 2000, 170-171). Tal cargo, como señala Zucca, implica la organización administrativa-religiosa del antiguo asentamiento talayótico en el ager de Mago, mediante la instauración de un compitum (centro de culto de los barrios o vici), y su respectiva capilla (sacellum o aedes), donde se veneraba al genio del emperador y sus lares, los cuales contaban habitualmente con dispositivos iconográficos de culto (Ovidio, Fasti 5, 145-146; Kunckel, 1974). El culto en los compita a los Lares Augusti se constata en Mallorca (Durán 2007, 69-70), concretamente en

16. Los conocimientos sobre la población instalada en la ensenada de Sanitja son aun fragmentarios, distinguiéndose un campamento militar tardo republicano instalado el la zona oriental, cuyos niveles excavados arrojan un uso hasta el 45 a.n.e. (Contreras et alii, 2006), pero en el que se aprecian cerámicas imperiales en superficie (Rita, 2007, 130), y en la zona occidental un complejo asentamiento con niveles estructurales que llegan a la antigüedad tardía, entre los que se han identificado elementos monumentales marmóreos de época alto imperial (Rita et alii, 1984; Juan i Benejam, 1993, 45, fig. XIV; y fig. 5 de este artículo), además de cerámicos (De Nicolás, 1983, 266; Orfila, 1995, 240), todo lo cual plantea la ocupación continuada del enclave desde la conquista del 123. el territorio bochoritano, a través de la dedicación a los Lares pro salute principis nostri realizada por $O p$ tato Severo, quien ofrece varios objetos destinados a los ritos practicados ${ }^{17}$, los cuales implican la existencia de una capilla o aedes equivalente a la inferida en Trepuco.

Ceremoniales de exaltación de poder de Roma se constatan también en el Fondeadero de Cales Coves según las investigaciones que se están realizando en los últimos años sobre los paneles epigráficos de la Cova dels Jurats (Mayer, 1996: 40; Zucca, 1998, 201, nota 47; Orfila et alii, 2010). Las infraestructuras documentadas consisten en una serie de tres cavidades de planta cuadrangular recortadas sobre una repisa natural en el acceso de la cueva que implican la existencia de sendas estatuas, frente a las cuales se conservan indicios de la existencia de tres altares de ofrendas. Dichas infraestructuras se encuentran relacionadas espacialmente con la pared donde se encuentran los 29 paneles epigráficos datados por fechas consulares en los ss. II-III d.n.e., en los cuales se observa dedicatorias de formulación reiterada, donde se hace referencia a la festividad de los Parilia del 21 de abril, la celebración del dies natialicivs vrbis (el aniversario de Roma), y de modo secundario posiblemente se haga referencia también a los ludi cereales (Orfila et alii, 2010, 463-464), todo lo cual indica la existencia de un grupo de estatuas de medio/gran formato posiblemente relacionado con tales festividades, tal vez un grupo capitolino, o incluso imágenes dinásticas imperiales.

Además de estas manifestaciones de carácter oficial, la iniciativa evergética privada supuso también la inclusión en el paisaje municipal de otro tipo de cultos que implican la existencia de elementos iconográficos que constituirían importantes hitos religiosos de las ciudades. Entre estos resultan muy conocidos los de Magna Mater y Attis, a los que se les dedica un templum en Mago (CIBal, 119; Zucca, 1998, nº 39; García Riaza y Sánchez León, 2000, 191), de cuyo simulacrum, habitualmente imágenes sedentes y helenizadas de la diosa, con frecuencia inspiradas en el modelo del Metroon del Ágora de Atenas atribuido a Agorakritos (Simon, 1997, 754; Nikoloska, 2011), no se han conservado restos $^{18}$, o Luna, cuya dedicación por parte el miles C. Iulius Flavius (CIBal, 163; Zucca, 1998, n 36) consistiría según la formulación del texto y las características del soporte del epigrafe, en un altar, una

17. Cuatro pedestales, un incensario, una urna sepulcral, una lámpara de bronce, una moneda de bronce, cuatro tablas pintadas de esmalte, un escudo y un velo (CIBal, 20).

18. La excepcionalidad de la inclusión de Attis en la dedicación magontana, ya señalada por García y Bellido (1967, 42), coincide con la escasez de grupos iconográficos de ambas divinidades, conocidas principalmente por algunos relieves y piezas de pequeño formato (Simon, 1997). 

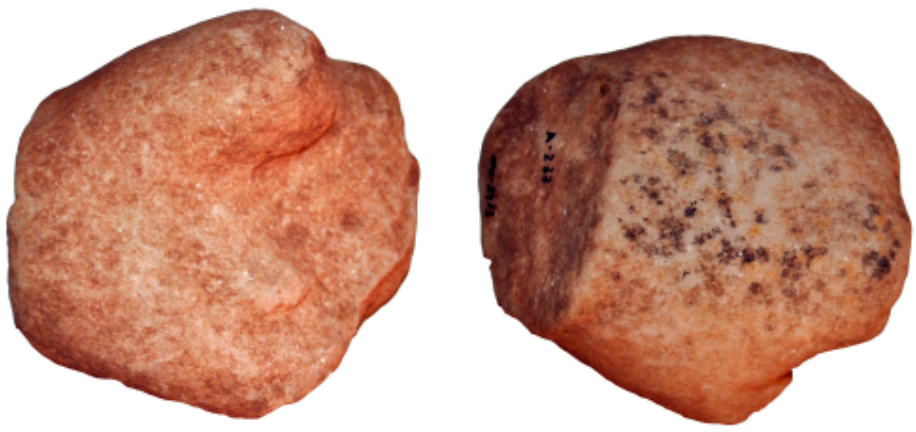

Fragmento de mano de Sanitja, Museo Municipal de Ciutadella MMC-2473
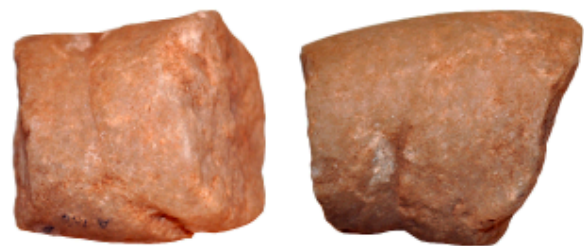

Fragmentos de brazo, sa Comerma de Sa Garita, Museo Municipal de Ciutadella, MMC-2472
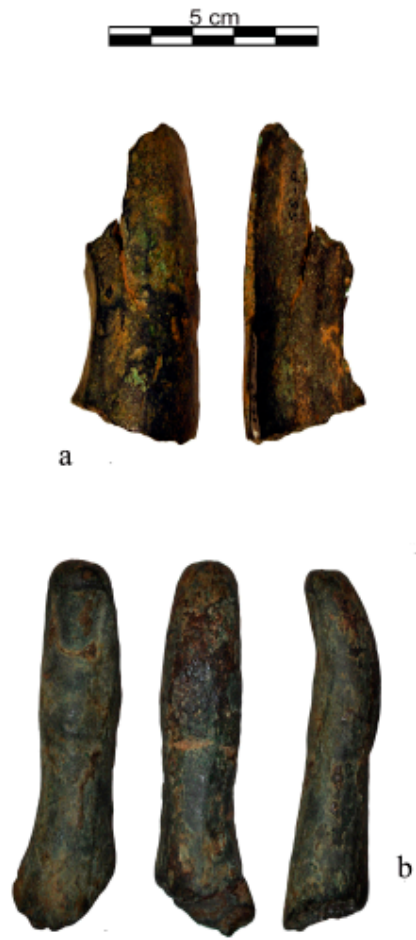

Fragmentos de estatuaria de Son Salomo a) Museo Municipal de Ciutadella (2471) b) Museo Diocesano de Menorca

Figura 5: Materiales de medio y gran formato.

estatua $^{19}$, según apuntó Rafael Oleo quien calificó el soporte como pedestal, o incluso puede hacer referencia a un posible aedes en Iamo (Zucca, 1998, 157).

Ante estas evidencias sobre los cultos civicosoficiales y su expansión en el territorio insular, los materiales iconográficos asociados son muy escasos y presentan además un estado sumamente fragmentario que impide en líneas generales su identificación (Fig. 5). Entre estos cabe mencionar los restos de estatuario broncínea de gran formato procedentes del yacimiento de Son Salomó (Ciutadella), realizados con técnicas propias de las fundiciones helenísticoromanas, o el fragmento de brazo de mármol de una estatua de formato mediano procedente del yacimiento de Sa Comerma de Sa Garita ( $n^{\circ}$ 26, Fig. 5), cuyas características indican que se trataba probablemente de una estatua ideal. La presencia de una probable estatua ideal coincide en líneas generales con la definición preliminar realizada sobre este yacimiento aun sin excavar, provisto de arquitectura monumental de prestigio y que pudo ostentar una funcionalidad de

19. Las imágenes antropomorfas de Luna, derivadas de la iconografía de Selene, con quien estaba profundamente sincretizada, se caracterizan por la representación de joven ataviada al modo griego y con el creciente lunar sobre la cabeza, conocido sobre todo en obras de pequeño formato (Gury, 1994, 706-715). tipo cultual (Plantalamor, 1991, 395), donde pudieron tener cabida imágenes de culto o exvotos escultóricos. Menos indicios de relación con la imaginería religiosa presenta el fragmento de mano marmórea recuperado casualmente en Sa Nitja y asociado a la civitas de Sanisera, de características igualmente propias de la estatuaria icónica de gran formato (funeraria y honorífica), ampliamente constatadas en asentamientos urbanos, siendo uno de los escasos documentos materiales de estas características conocidos en la isla.

\section{DIOSES Y CREENCIAS EN EL ÁMBITO RU- RAL DURANTE LA ÉPOCA IMPERIAL.}

Sobre la penetración en la esfera privada de cultos y creencias romanas en Menorca hay constancia a través de una serie de piezas de pequeño formato, las cuales pueden dividirse en dos grupos: imágenes relativas al ámbito de las creencias, e imágenes de divinidades.

Las primeras pueden dividirse a su vez en objetos de uso mágico producidos ex profeso para estos fines, y piezas, bien exentas o apliques del ajuar doméstico, donde quedan implícitos aspectos culturales y creencias populares pero cuya producción se realiza también con una finalidad ornamental. Los primeros están representados por un fascinum, o amuleto fálico, procedente de Pleta de Ses Lluques (Algaiarens, $\mathrm{n}^{\circ}$ 19, Fig. 6), un sector de la isla donde los hallazgos en 


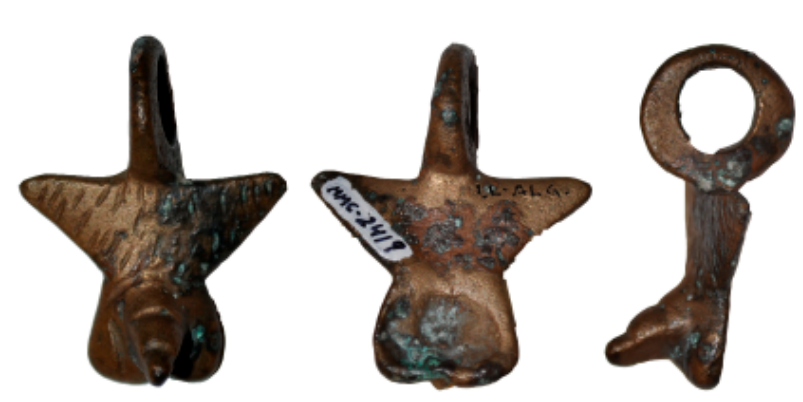

Figura 6: Colgante fálico de Algaiarens.

superficie plantean un poblamiento de época republicana e imperial con posibles patrones de asentamiento de tipo romano (De Nicolás, 1991; 2003, 121; Orfila, 1995, 245).

La idea del falo como protector de sortilegios y espíritus malignos está presente ya en Grecia, adquiriendo en Roma un culto prácticamente institucionalizado, en el que el phallus formaba parte de determinadas ceremonias públicas, para prevenir miradas adversas, y cuyo uso profiláctico se aplicó mediante representaciones icónicas a todo de tipo de edificios, públicos y privados; en diversos objetos de la vida cotidiana, tales como vasijas y lucernas; así como en elementos del atuendo personal, como fíbulas y colgantes, como el ejemplar de Algaiarens. Este tipo de representaciones carecen por lo general de valor artístico o estético, concentrándose su importancia en sus propiedades mágicas, principalmente como ahuyentadores del mal de ojo (fascinatio) y la envidia (inuidus) (Plinio, Nat. His. 28, 39), y que en el caso de los colgantes se asocian con frecuencia a la protección de niños hasta alcanzar la pubertad (Varrón, De lengua latina 7, 87), mujeres, o militares ${ }^{20}$. El colgante menorquín, enmarcado en el tipo de «colgante simple de Frente» (Del Hoyo y Vázquez Hoys, 1996; Vázquez Hoys, 2009, $53)$, presenta importantes paralelismos con piezas de la provincia tarraconense, en particular con determinados ejemplares procedentes de las principales urbes costeras, encuadrados entre los ss. I-II d.n.e. (Ejemplares de Carthago Nova: Martín, 2009, y Tarraco: AAVV, 1990, 248, n 161), los cuales presentan suficientes elementos diferenciadores respecto a colgantes del tipo realizados en otras provincias como para plantear su producción peninsular.

Sobre el segundo grupo de imágenes, son representativos diversos objetos figurados del ajuar doméstico que tienen como objeto la representación social de sus poseedores incidiendo en sus aspectos de calidad ornamental, pero al mismo tiempo están conectados con el entramado de creencias, tal y como muestra por

20. Recientemente se ha recuperado un amuleto de este tipo en el interior del campamento militar de A Cidadela, Galicia (Costa, 2011, 759).

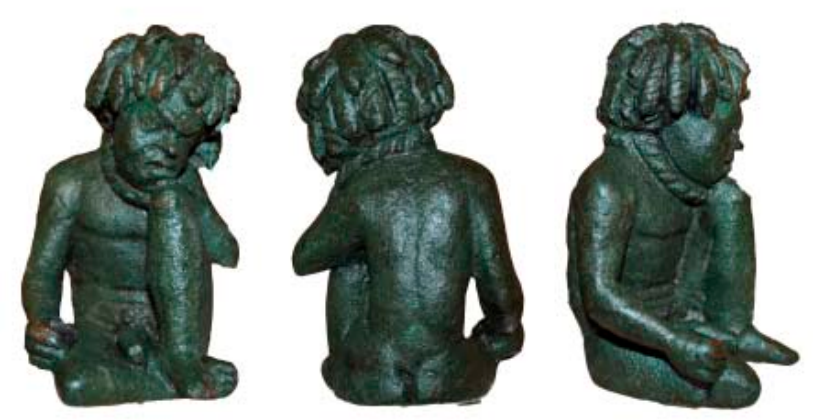

Figura 7: Esclavo itifálico de Son Catlar.

ejemplo un aplique menorquín de lucerna broncínea con representación de un ratón ( $\left.n^{\circ} 24\right)$, caracterización frecuente en lámparas que parece responder a las consideraciones sobre la extraordinaria fecundidad (Plinio, Nat. His. 10, 185), su asimilación simbólica con los recursos domésticos (Artemidoro, Oneirokr. 3, 28), e incluso la importancia para los presagios privados y públicos (Plinio, Nat. His. 8, 221) que recaen sobre este animal en la cosmovisión de la época. En una situación similar se encuadrarían otras estatuillas zoomorfas conservadas en la HSA, en concreto dos machos de oveja y cabra respectivamente $\left(\mathrm{n}^{\mathrm{o}} 22\right.$ y 23 , respectivamente), cuyas connotaciones económicas, medicinales $^{21}$, y simbólicas ${ }^{22}$, influyeron en el empleo de este tipo de figurillas como objeto votivo, en los ajuares funerarios, y como numen profiláctico doméstico, como se ha propuesto al respecto de un ejemplar sin vellones de estilo muy similar al carnero menorquín (Galliazzo, 1979, 121, nº 33).

También prestigiosos objetos figurados presentan características que remiten a ciertas atribuciones apotropaicas, entre los que destaca el esclavo negro itifálico (n $n^{\circ}$ 20, Fig. 7) del poblado talayótico de Son Catlar, uno de los poblados más importantes del sector suroccidental de la isla y, como la mayoría de asentamientos de este tipo, con materiales imperiales en superficie que indican su continuidad cronológica en época romana (Orfila, 1995, 244).

$\mathrm{Su}$ alta calidad, y su posible función como ornamento de un elemento mobiliario ${ }^{23}$, lo convierten sin duda en un objeto de prestigio que hace alusión además al tema del esclavo y sirviente doméstico. Pero además de satisfacer la demanda de objetos suntuarios

21. Principalmente atribuidas a la lana, Plinio, Nat. His. $8,47,191$.

22. En el mundo greco romano, la importancia del macho viene señalada desde el propio léxico, ya que la voz krios significa «carnero», y el participio kreion era empleada en el lenguaje épico con el valor de «soberano», «jefe», como afirma Artemidoro en el s. II dne (Oneirokr. II, 12).

23. Un ejemplar de joven itifálico en posición postrada, de dimensiones similares a este menorquín, conserva la base para adosar posiblemente a un candelabro (Boube-Picot, 1975, 319, n 590). 

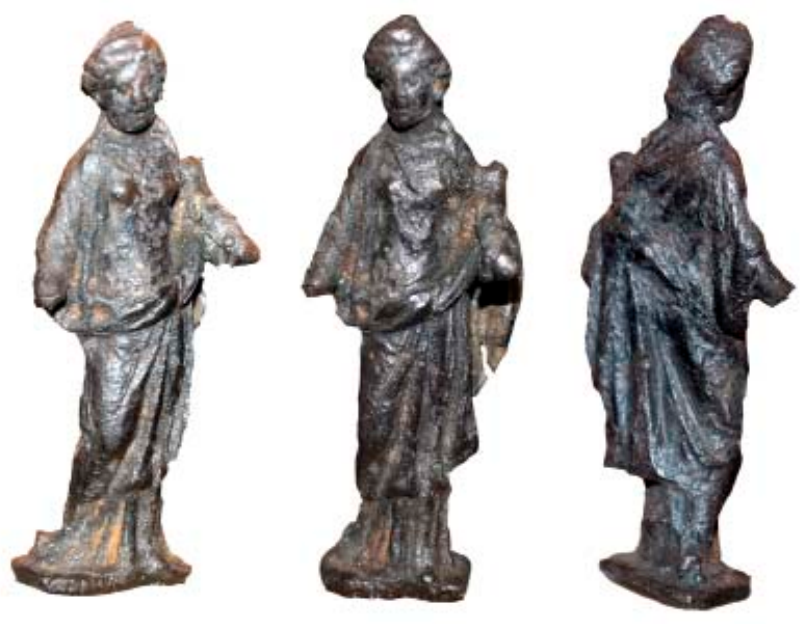

Fig. 8. Fortuna del predio de Biniatzem.

de ambientación alejandrina, las conocidas imágenes itifálicas de enanos o negroides, presentan también un carácter apotropaico y supersticioso que se produce por mecanismos similares a los de la imagen fálica en general (Clarke, 2007), y que se constata también en suntuosas piezas como balsamarios en forma de busto de negroide con amuletos fálicos colgados al cuello (Vázquez Hoys, 2009, 59).

Por otra parte, un importante conjunto de figuraciones plásticas corresponden a divinidades de gran popularidad y difusión geográfica, cuya penetración en distintos estratos sociales se debe a sus múltiples atribuciones y esferas de poder.

Los documentos de este tipo en Menorca proceden en la mayoría de los casos de antiguos asentamientos talayóticos con pervivencia en época imperial, y presentan características atribuibles en principio al ámbito privado, frecuentemente formando parte del ajuar litúrgico doméstico. Es muy probable, por tanto, que tales divinidades, representadas a través de sus correspondientes estatuillas, fueran objeto de culto en los distintos asentamientos de la isla, si bien la falta de contextualización arqueológica de casi todas impide precisar su empleo como imágenes de culto domésticas o como exvotos en centros cultuales colectivos, habida cuenta del desarrollo de esta práctica en el periodo postalayótico. Además de las ya comentadas imágenes de Júpiter y Minerva, una de las piezas más conocidas es la estatuilla de Mercurio procedente de San Joan de Carbonell ( $\mathrm{n}^{\circ}$ 9), una divinidad con un amplio espectro de atribuciones ${ }^{24}$, entre las que destacan

24. «..Hermes resulta propicio a los que se dedican a la oratoria, a los atletas, a los entrenadores deportivos, a todos los que se ganan la vida con el comercio y a los que vigilan los pesos y las medidas por pensarse que este numen es el protector de todos estos profesionales. Es también favorable a los que proyectan un viaje, ya que suponemos que es un ser alado...[.]...a los enfermos los extermina, por ser considerado el conductor de las almas al más allá..»(Artemidoro, Oneirokr., 2, 37). en el ámbito popular su capacidad como dispensador de lucrum asociado a las transacciones comerciales ${ }^{25}$. La pieza, fechable por la configuración blanda de la anatomía, y del cabello entre la etapa julio claudia y el reinado de Trajano, se adscribe a la variante que cubre el costado izquierdo, también conocida como clámide en «V» o triangular (Franzoni, 1973, 59-60; Boucher, 1976, 81-84, plano X), una de las más frecuentes en Italia (Oggiano-Bitar, 1994, 318), y Baleares, con otros dos ejemplares de Pollentia (Pozo, 1989: 70-72), encontrándose de modo secundario frente a otras tipologías en el litoral tarraconense (Baratta, 2001; Arasa, 2008, 430). El hallazgo se produjo en las inmediaciones del puerto natural de la Bahía de Fornells, donde se han localizado algunos yacimientos de cronología romana, en un sector con actividad pesquera y de explotación de sal evidenciada por restos en superficie (Juan i Benejam, 1993, 45-46), por lo que la estatuilla se ha relacionado con la protección de tales actividades comerciales (Casesnoves, 1988, 62, nota 20).

Otra divinidad de amplias atribuciones, como Fortuna, está representada por un bronce inédito procedente de los terrenos del predio de Biniatzem (Es Migjorn Gran, $n^{\circ}$ 4, Fig. 8). Antigua divinidad agraria sincretizada con el culto de Tyche griega, adquiere en época romana gran popularidad e importancia como regidora de los azares y cuyo ámbito de poder se extiende sobre personas, objetos, lugares, y acontecimientos, dando una idea de sus múltiples atribuciones los diversos centros de culto en Roma donde se la venera bajo distintos epítetos (Champeaux, 1982, 463-466). Tales atribuciones se extienden al ámbito de la familia romana, al tiempo que la diosa ejerce una protección individual sobre cada persona, todo lo cual explica las frecuentes imágenes de la diosa en contextos privados de culto, especialmente en soportes pictóricos y escultóricos de pequeño formato en los lararios domésticos, tanto en Italia, como evidencian los lararios campanos, donde es una de las divinidades más frecuentes (Fröhlich, 1991, 51-52), como en las provincias, incluyendo las hispanas (Fernández et alii, 2011).

La pieza menorquina, fechable en el s. II d.n.e., y adscrita a una tipología de origen griego con amplia difusión geográfica empleada también en la estatuaria de culto e icónica de gran formato (Rausa, 1997, 127-128), presenta defectos de fundición que afectan a distintas zonas de la figurilla, así con un breve plinto para apoyar la estatuilla sin el concurso de pequeños pedestales exentos de bronce, aspectos técnicos que inciden en su pertenencia a un ambiente doméstico no

25. Combet-Farnoux, 1980. El culto de Mercurio en las áreas comerciales de Pollentia (Mallorca) está perfectamente constatado a través del material iconográfico, y su investigación forma parte de la tesis doctoral «Estudio y contextualización de la escultura en la ciudad romana de Pollentia» que está desarrollando actualmente quien suscribe este artículo. 
necesariamente acomodado, y en la valoración de las propiedades religiosas implícitas en la estatuilla.

Venus, otra de las divinidades oficiales del panteón romano, pudo recibir culto en Menorca según dos pequeños bronces conservados ( $n^{\circ} 14$ y 15$)$, cuyas características son con frecuencia asociadas a los cultos domésticos en los lararios (Fernández, 1998; AdamoMuscettola, 1984, 24-26), donde, al margen de sus atribuciones oficiales, la diosa tiene importantes atribuciones de fertilidad, matrimonio, y los ciclos de la vida.

Claras atribuciones funerarias se han documentado en el caso de dos pequeños apliques con representaciones del cortejo de Eros, que formaban parte de uno de los ajuares de la necrópolis de Binigafull ( $\left.n^{\circ} 3\right)$, con materiales que indican su continuidad entre los ss. I y V d.n.e. (De Nicolás, 1983, 268; Orfila, 1995, 251). Las atribuciones funerarias de Eros y su sequito de erotes, están sobradamente atestiguadas en la documentación iconográfica (Söldner, 1986, 332), constatándose máscaras muy similares a las menorquinas en terracotas de necrópolis helenísticas (Besques, 1963, 36), así como estatuillas del dios en ajuares funerarios de época imperial ${ }^{26}$ del sector costero tarraconense (Arasa, 2008, 442-443). La estrecha similitud técnica y estilística con dos ejemplares de Legs Lambert, en Galia (Boucher, 1970, 10, $\mathrm{n}^{\circ}$ 19), que repiten exactamente el esquema de los menorquines, plantea un origen galo para las piezas.

Connotaciones funerarias se atribuyen también a la tipología del Eros, o genio fúnebre, procedente de Torre Vella d'en Lozano ( $\left.\mathrm{n}^{\circ} 1\right)$, según el simbolismo de la antorcha girada hacia la tierra alegórico de la extinción de la vida ${ }^{27}$. No obstante, se trata de una pieza procedente de un contexto de hábitat, que pudo formar parte igualmente de un dispositivo de culto u ornamental privado. De hecho, el tipo, atribuido al periodo helenístico y que aparece en el naufragio del Madhia hacia el 86 a.n.e. (Fuchs, 1963, 21, no 14), gozó de popularidad en época imperial principalmente contextualizado en contextos domésticos acomodados. Una función similar desempeñaría otra estatuilla inédita y fragmentaria de Eros procedente de Menorca, conservada en la HSA ( $\left.n^{\circ} 2\right)$, que formaría probablemente parte de un pequeño grupo de temática mitológica.

26. Por otra parte, la inclusión de apliques broncíneos en los ajuares funerarios ilustra una práctica generalizada en las concepciones escatológicas romanas según la cual los ajuares tratan de proporcionar en la medida de las posibilidades económicas los objetos cotidianos y las imágenes de genios o divinidades que contribuyan a la protección y amparo del difunto (Prieur, 1991).

27. Cumont, 1942, 341, 409, 411, 444. La interpretación se ha aplicado por ejemplo a un ejemplar de Volubilis hallado en una zona de tabernae (Boube-Picot, 1969, 212). Una iconografía muy similar se muestra en una lucerna cerámica de época alto imperial procedente de la necrópolis de Binigafull (De Nicolás, 1983, 267-268, fotografía en p. 201).
Cultos orientales, en concreto relacionados con la religión isiaca, están también constatados en materiales de pequeño formato. El bronce de Isis-Fortuna de la colección Pons i Soller, procedente de Biniparraxet ( $\mathrm{n}^{\mathrm{o}}$ 16, Fig. 9c), corresponde al sincretismo operado en la Grecia helenística con Tyche a partir de finales del s. III a.n.e., según el cual era venerada como Isis Pelagia, señora del mar y de la feliz travesía, bajo cuya advocación se celebraba en todos los puertos romanos el Navigium Isidis del 5 de marzo, ceremonia con la que se inauguraba la temporada de navegación (Turcan, 1989, 114-118). La estatuilla, cuyo modelo procedería de un arquetipo común helenístico, atribuido a la escuela de Rodas a mediados del s. II a.n.e. (Frapicini, 1990, 186-188, nota 33), se adscribe a una variante iconográfica muy abundante en pequeños bronces, perteneciente al tipo D de la clasificación de Tran Tam Thin (1990, 785-786), cuyos ejemplares se distribuyen especialmente en occidente con importantes focos de concentración en las ciudades costeras de Campania, y del norte de Italia, especialmente en la región adriática, en alguno de cuyos talleres debió fundirse el ejemplar menorquín, prácticamente idéntico a una pieza de Copermio, en la región parmense ( $\mathrm{D}^{\prime}$ Andria, 1970, $\left.105, \mathrm{n}^{\mathrm{o}} 165\right)$. Estatuillas de este tipo son frecuentes en los lararios, si bien se conocen conjuntos de materiales iconográficos protohistóricos procedentes del yacimiento de Biniparraxet, como serían el bronce helenístico de Odiseo (Orfila, 1982-83, 133-134), o el conjunto de terracotas púnicas de la colección Pons i Soller, que han dado pie a plantear la existencia de un santuario con importante presencia de material figurado (De Nicolás, 1983, 210-211), por lo que no puede descartarse por el momento una posible continuidad en época imperial romana, y por tanto el empleo como exvoto de la estatuilla de Isis.

Menos conocidos son otros dos documentos iconográficos, conservados en la HSA, que remiten con probabilidad a los cultos isiacos. Uno de ellos es un fragmento de brazo izquierdo que lleva en la mano un oinochoe, perteneciente a una estatuilla de dimensiones algo superiores a las habituales, entre los $15-25 \mathrm{~cm}$ de altura aproximadamente, procedente del poblado de Biniatram ( $\mathrm{n}^{\mathrm{o}}$ 17, Fig. 9b). Los elementos conservados remiten a reelaboraciones de un original helenístico (Tran Tam Tinh, 1984, 1725), en la que Isis porta los atributos tradicionales: el sistro, instrumento musical litúrgico asociado a su culto, y el recipiente, en este caso un oinochoe, constatado principalmente en estatuas de medio/gran formato fechadas en el s. II d.n.e. (Eingartner, 1991, 140), y cuyo único paralelo localizado en pequeños bronces procede de un ejemplar fragmentario de Velleia, de nuevo en el norte de Italia, fechado en el s. II d.n.e. (Arslan, 1997, 472, cat. V, 126).

La otra pieza, un aplique de morfología cilíndrica, con representación de un personaje de rasgos demacrados y orejas apuntadas, envuelto en una serpiente que ciñe completamente la mitad inferior del cuerpo y repta por el torso hasta alcanzar la cabeza y la zona 


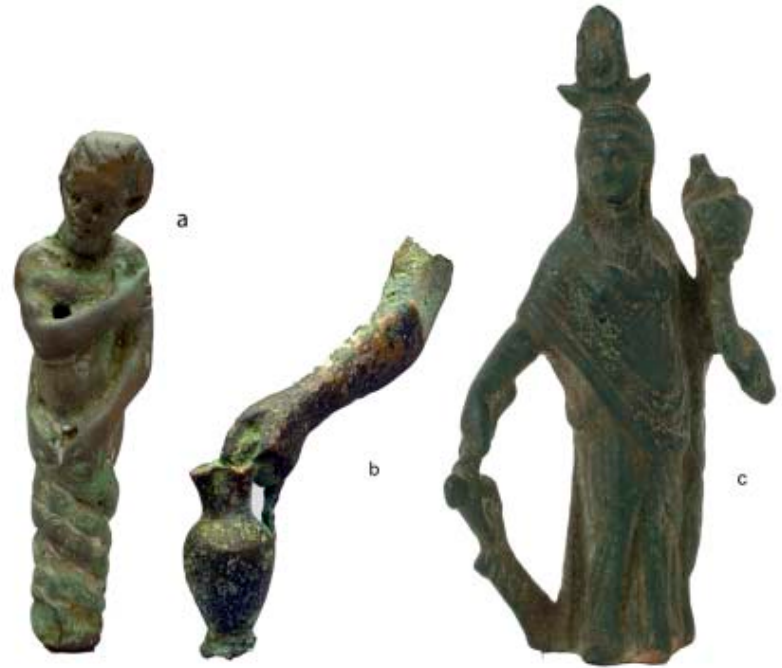

Figura 9: a) figura masculina relativa a los cultos de Isis-Osiris; b) fragmento de posible estatuilla de Isis. (Fuente: HSA). c) estatuilla de Isis-Fortuna de Biniparraxet.

derecha del pecho, remite a los cultos de Isis-Osiris $\left(n^{\circ}\right.$ 18, Fig. 9a). La identidad del personaje es incierta, remitiendo en líneas generales a las figuraciones de fieles ${ }^{28}$ y sacerdotes, entre las que pueden señalarse algunos apliques de objetos litúrgicos de morfología similar a la pieza menorquina (Di Stefano, 1975, 87$88 ; \mathrm{n}^{\circ} 155$, tav. 33). La relación con Osiris, pareja mítica de Isis, se evidencia por el tema de la serpiente que se enrosca ciñendo el cuerpo del personaje, y que remite al ámbito iconográfico del dios en su acepción de Chronokrator, señor del tiempo, con paralelos en la estatuaria romana de gran formato (Bresciani, 1997, 231-234), acepción muy vinculada a los cultos de resurrección-regeneración representados por el dios, y que en Roma se manifestaron en la festividad imperial de las Isia, entre el 28 de octubre y el 3 de noviembre.

\section{A MODO DE CONCLUSIÓN}

Desde el punto de vista del material iconográfico, Menorca presenta entre los ss. IV-III a.n.e. y el final de la república romana un complejo mosaico de imágenes, entre las que pueden distinguirse determinadas temáticas de profundo calado en la cosmovisión postalayótica, contextualizándose en el ámbito funerario $\mathrm{y}$ en las edificaciones de prestigio de los poblados, $\mathrm{y}$, paralelamente, imágenes foráneas importadas del ámbito mítico-religioso helenístico, púnico, e itálico, estas últimas a partir del s. II a.n.e., todo lo cual refleja el heterogéneo panorama cultural de la isla originado por la cada vez más efectiva integración de esta en la dinámica histórica y cultural de las grandes potencias mediterráneas.

La presencia de tropas militares romanas desde la conquista del 123 a.n.e., la ausencia de entidades cívicas municipales hasta la época flavia, y la exaltación mítica del belicismo en la cosmovisión postalayótica que se refleja en las estatuillas de las denominadas divinidades bélicas, pudieron generar un ambiente cultual de cierta continuidad de la influencia indígena distinto

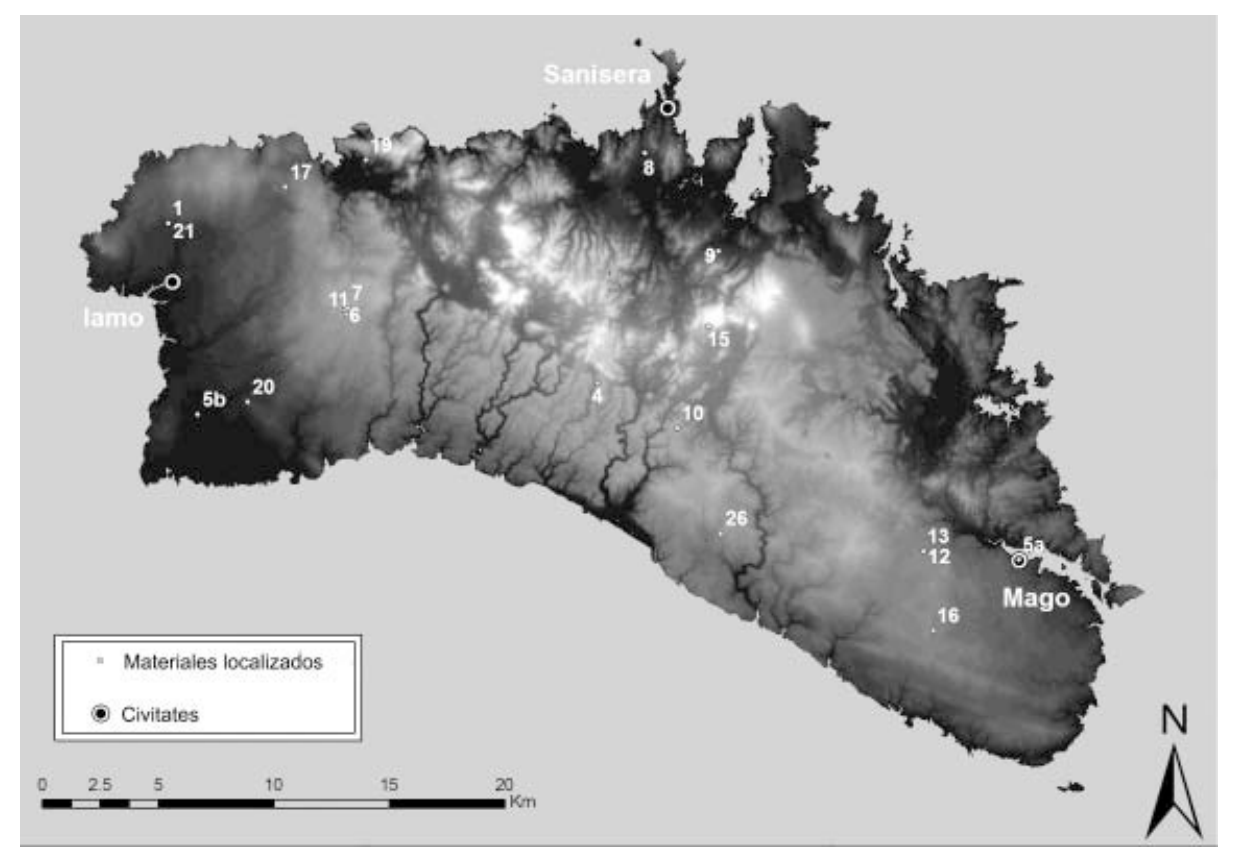

Figura 10: Localización de los materiales iconográficos de procedencia conocida (Fuente: Mario Gutiérrez, UGR).

28. Por ejemplo, una representación votiva de viejo procedente del Iseum Campensis, (Roullet, 1972, 241, n² 216, pl. 169). 
del desarrollado en Mallorca, caracterizado por la instalación de colonias con un importante componente de religiosidad civil/oficial. Estas circunstancias, unidas a la integración de los auxilia baleáricos en el ejército romano desde la Segunda Guerra Púnica, fomentarían el culto a divinidades «de fuerza» provistas de importantes atribuciones bélicas, como puede ser el caso de las dos estatuillas de Hércules, con indicios de su producción local entre los ss. I a.n.e.-I d.n.e., una divinidad recientemente constatada en contextos domésticos indígenas del s. II a.n.e. (Torre d'en Gaumés).

El material iconográfico asociado a conductas oficiales de Roma documentado en la isla se retrasará hasta la época julio claudia, inicialmente asociadas al ámbito militar, mientras a partir de la municipalización flavia de los principales enclaves urbanos se desplegarán dispositivos relacionados con la religiosidad civil, los cuales tendrán su reflejo en determinados puntos del territorio insular (como por ejemplo en Cales Coves). No obstante, la mayor parte de la documentación iconográfica conservada ilustra la generalización de cultos y creencias romanas en el ámbito privado, principalmente a partir del periodo de municipalización de las ciudades, y contextualizada en antiguos poblados talayóticos con pervivencia durante la época imperial (Fig. 10). Es durante este periodo post municipal en el que desaparecen los indicios de producción de bronces figurados que existían para la etapa postalayótica y comienzos de época imperial (caso de los Guerreros baleáricos o las estatuillas de Hércules), predominando un panorama de importaciones entre las que destacan las de los centros productores de Galia e Italia Septentrional.

\section{ANEXO 1: CATÁLOGO}

\section{Divinidades greco-romanas}

\section{1- Eros o genio danzante}

Bronce. Colección Mercedes Saura, dimensiones: 10 $\mathrm{cm}$ de altura, $7 \mathrm{~cm}$ de anchura. Bibliografía: Orfila y Sintés, 1980-84, 41; Orfila, 1982-83, 116, n 6a; 1995, 259, fig. 69; Casesnoves, 1988, 65; AAVV, 2005, 69, $\mathrm{n}^{\circ} 35$. Hallado fortuitamente en el yacimiento de Torre Vella d'en Lozano (Ciutadella) en 1866. La pieza fue fechada en los ss. II-III d.n.e. por Orfila y Sintés.

\section{2- Estatuilla fragmentaria de Eros}

Bronce. Hispanic Society of America, $n^{\circ}$ de inv. D928, dimensiones: 5,8 cm de altura. Bibliografía: García y Bellido, 1993, 266, lám. 294-2. Procede de Menorca, adquirido en una tienda de Mahón. Perteneció a la Colección Vives. Época alto imperial.

\section{3-Apliques con representación de máscara de Eros}

3a. Bronce. Museo Diocesano de Menorca, $\mathrm{n}^{\mathrm{o}}$ inv MDM-415 A129; 3b. Bronce. MDM-416 A 130; dimensiones: ambos presentan $3,2 \mathrm{~cm}$ de altura y $3 \mathrm{~cm}$ de anchura; 1,2 cm de grosor. Bibliografía: Orfila, 1982-83, 109, $\mathrm{n}^{\mathrm{o}} 1 \mathrm{~d}$. Pertenecientes a un ajuar funerario de la necrópolis romana rural de Binigafull (Ciutadella). ss. II-III d.n.e.

\section{4- Fortuna (Fig. 8)}

Bronce. Museo Diocesano de Menorca, $\sin n^{0}$ de inventario, dimensiones: $4,2 \mathrm{~cm}$ de altura; $2,2 \mathrm{~cm}$ de anchura; $0,8 \mathrm{~cm}$ de grosor. Inédita. Hallada en los terrenos del predio de Biniatzem (Es Migjorn Gran), adquisición de la colección León Mercadal. s. II d.n.e.

\section{5- Hércules (5a: Fig. 1c, 5b: Fig. 1d)}

5a. Bronce. Hispanic Society of America, $n^{0}$ de inv. D906, dimensiones: $11,3 \mathrm{~cm}$ de altura; $5,5 \mathrm{~cm}$ de anchura. Bibliografía: Ramis, 1833, 32; Casesnoves,
1988, 61-62; García y Bellido, 1993, 258, lám. 166-8. Se trata de la estatuilla cuyo hallazgo sitúa A. Ramis en un huerto «a lo último» de la calle Cos de Mahón. De la colección Ramis pasó a la Vivés, y de esta a la institución norteamericana donde se conserva actualmente. 5b. Bronce. Paradero actual desconocido, dimensiones iguales a la figura anterior, según apunta su primer propietario A. Ramis. Bibliografía: Ramis, 1833, 32; Hernández Sanz, 1908, 126; Orfila, 1982-83, 124, n ${ }^{\circ}$ 9, fig. 19; 1995, 261, fig. 72; Casesnoves, 1988, 61-62. Hallazgo casual de 1832 en el predio de Sant Antoni, vulgo de Son Olivaret

(Ciutadella). Ambas piezas de finales s. I a.n.e. - s. I d.n.e.

\section{6- Júpiter, variante del tipo tonante}

Bronce. Colección particular. Bibliografía: Serra et alii, 1977, 91, fig. 36; Orfila, 1982-83, 132-133, no 14; De Nicolás, 1983, 277; Casesnoves, 1988, 60. Procedente del poblado de Torre Trençada (Ciutadella), hallazgo casual entre 1970-80. Época antoniniana o severa.

\section{7- Júpiter, tipo «Majesté»}

Bronce. Museo Diocesano de Menorca, procedente de la colección Manuel León Mercadal, dimensiones: 6,4 $\mathrm{cm}$ de altura, 3,2 $\mathrm{cm}$ anchura máxima. Bibliografía: Casesnoves, 1988, 60; Orfila, 1995, 261; AAVV, 1998, 40. Hallazgo casual de 1941, al efectuar remociones agrícolas en Tanca des Vell, cerca del poblado de Bellaventura y en terrenos de Torre Trençada (Ciutade1la). ss. II-III d.n.e.

\section{8- Marte juvenil, tipo «Tänzer» (Fig. 4b)}

Bronce. Colección De Olivar (Ciutadella), dimensiones: $20 \mathrm{~cm}$ de altura. Bibliografía: Hernández Sanz, 1908, 127; Llompart, 1960, 105-106; 1970: 234; Orfila, 1982-83, 119, no 8d; 1995, 241, fig. 45 Casesnoves, 1988, 62. Hallado en el poblado de Pujol el Antic de Cavallería. Primera mitad del s. I d.n.e. 


\section{9- Mercurio, tipo de clámide triangular o en «V》}

Bronce. Hispanic Society of America, $\mathrm{n}^{\circ}$ de inv. D902, dimensiones: $11,2 \mathrm{~cm}$ de altura; $6 \mathrm{~cm}$ de anchura. Bibliografía: Fernández de Avilés, 1962, fig. 3c; Orfila, 1982-83, 124-125, no 10; 1995, 261; Casesnoves, 1988, 62; García y Bellido, 1993, 266, lám. 294-3; AAVV, 2005, 66, $\mathrm{n}^{\circ}$ 24. Hallado en San Juan de Carbonell (Mercadal), junto a la Bahía de Fornells. s. Icomienzos del s. II d.n.e.

\section{0- Minerva, variante del tipo Giustanini}

Bronce. Colección De Olivés, dimensiones: 7,8 cm de altura; $2,9 \mathrm{~cm}$ de anchura; y 2, $1 \mathrm{~cm}$ de grosor. Bibliografía: Orfila, 1982-83, 133, fig. 24 bis; 1995, 261; Casesnoves, 1988, 60-61; AAVV, 2005, 66, $\mathrm{n}^{\circ} 28$. Hallada en el entorno del Talayot de Santa Creu, en 1882. s. I-II d.n.e.

11- Aplique en forma de busto de Minerva (Fig. 3) Bronce. Museo Diocesano de Menorca, $\mathrm{n}^{\mathrm{o}}$ de inv. MDM-811 A 525, dimensiones: $2,8 \mathrm{~cm}$ de altura, 2,2 $\mathrm{cm}$ de anchura; grosor: $0,4 \mathrm{~cm}$. Inédita. Hallazgo fortuito en los terrenos del predio de Torre Trençada. Finales del s. III d.n.e.

\section{2- Entalle con representación de Sátiro}

Ágata. Museo de Menorca, ${ }^{\circ}$ de inv. 43101, dimensiones: $1,7 \mathrm{~cm}$ de diámetro, grosor de $3,5 \mathrm{~mm}$. Bibliografía: Pons, 2005, 41, lám.12. Hallado en la campaña de 2001 en el poblado de Talatí de Dalt (Mahón), concretamente en el nivel superficial (UE 1), a unos 100 $\mathrm{m}$ al SO de la Taula. S. II-I a.n.e. (integrado entre los materiales de la Fase II del poblado).

\section{3- Aplique en forma de máscara de Sátiro - Somnus}

Bronce. Museo Diocesano de Menorca, $\mathrm{n}^{0}$ de inv MDM-815 A529, dimensiones: 3,4 cm de altura; 3,6 $\mathrm{cm}$ de anchura; $1,4 \mathrm{~cm}$ de grosor. Inédito. Hallazgo casual en el poblado de Talatí de Dalt (Mahón), adquisición por compra de la colección León Mercadal. Epoca alto imperial.

\section{4- Venus, variante del tipo capitolino}

Bronce. Hispanic Society of America, $\mathrm{n}^{0}$ de inv. D911; dimensiones: $12,1 \mathrm{~cm}$ de altura. Bibliografía: Orfila, 1982-83, 137, no 22b; Casesnoves, 1988, 65; García y Bellido, 1993, 257, lám. 166; Fernández Uriel, 1998, 378-379, $\mathrm{n}^{\circ}$ 14. Procede de Menorca, colección Ramís, posteriormente en la Vivés, de donde pasó a la institución norteamericana. Época alto imperial.

\section{5- Estatuilla fragmentaria de Venus, del tipo del ajuste de sandalia \\ Bronce. Museo de Menorca, dimensiones: $11 \mathrm{~cm}$ de altura. Bibliografía: García y Bellido, 1948, 126, fig, 39; Orfila, 1982-83, 136-137, no 22a; 1995, 261; Ca- sesnoves, 1988, 65. Hallada en Rafal del Toro, perte- neció a la colección Vives. Alto imperial.}

\section{Cultos de origen oriental}

\section{6- Isis-Fortuna (Fig. 9c)}

Bronce. Colección De Olivés (Mahón), dimensiones: 9,8 cm de altura; $5,4 \mathrm{~cm}$ de anchura; $2,8 \mathrm{~cm}$ de grosor. Bibliografía: Hernández Sanz, 1908, 125; Orfila, 1982-83, 130-131, no 12; 1995, 261; Casesnoves, 1988, 66; AAVV, 2005, 66, $\mathrm{n}^{\circ}$ 27. Hallada en el predio de Biniparraxet a finales del s. XIX. Finales del s. I - s. II d.n.e.

\section{7- Brazo perteneciente a una estatuilla de divinidad, posiblemente Isis (Fig. 9b)}

Bronce. Hispanic Society of America, $n^{\circ}$ de inv. D921; dimensiones: Longitud: $6,9 \mathrm{~cm}$; altura de la jarra: 3,4 cm. Bibliografía: García y Bellido, 1993, 266-267, lám. 296-8. Hallado fortuitamente en el poblado de Biniatram (Ciutadella). s. II-III d.n.e.

\section{8- Aplique con figura masculina envuelta en una serpiente (Fig. 9a)}

Bronce. Hispanic Society of America, $n^{\circ}$ de inv. D917; dimensiones: $7,8 \mathrm{~cm}$ de altura. Bibliografía: García y Bellido, 1993, 266, lám. 294-4. Hallado en Menorca, lugar y circunstancias desconocidas. De la colección Ramis, de donde pasó a la Vives y a la institución norteamericana. S. I a.n.e. - s. I d.n.e.

\section{Material iconográfico relativo al ámbito de las creencias}

\section{9- Amuleto-colgante fálico (Fig. 6)}

Bronce. Museo Municipal de Ciutadella, $\mathrm{n}^{\circ}$ de inv. MMC-2419 (col. Sánchez); dimensiones: 3,8 cm de altura; 2,9 cm de anchura. Inédito. Hallado en Pleta de Ses Lluques, Algaiarens (Ciutadella). ss. I-II d.n.e.

\section{0- Esclavo negroide itifálico (Fig. 7)}

Bronce. Museo Diocesano de Menorca, sin $\mathrm{n}^{\circ}$ de inv.; dimensiones: $4,7 \mathrm{~cm}$ de altura; $3 \mathrm{~cm}$ de anchura (cabeza 1,8 cm de anchura). Bibliografía: AAVV, 1998, $121, \mathrm{n}^{\circ} 14$. Hallado fortuitamente en el poblado de Son Catlar, colección León Mercadal. ss. I a.n.e. - I d.n.e.

\section{1- Joven palliatus (Fig. 2)}

Bronce. Museo Municipal de Ciutadella, $\mathrm{n}^{0}$ de inv. MMC-2341 (col. Sánchez); dimensiones: 10,9 cm de altura; 3,6 cm de anchura. Bibliografía: AAVV, 1998, 114, $\mathrm{n}^{\circ} 7$; AAVV, 2005, 119, $\mathrm{n}^{\mathrm{o}}$ 139. Hallazgo fortuito del yacimiento de Torre Vella de'n Lozano (Ciutade1la). ss. II-I a.n.e..

\section{Estatuaria zoomorfa}

\section{2- Carnero}

Bronce. Hispanic Society of America, inv. D950. Dimensiones: $4 \mathrm{~cm}$ de altura; 4,7 de longitud. Bibliografía: Mélida, 1900, 409, lám XXI-68; García y Bellido, 1993, 266-267, lám. 296-2. Hallado en lugar 
indeterminado de Menorca. Mélida sitúa erróneamente el hallazgo en Mallorca, pero la correspondencia de Ramís con J. Ma . Bover de 1828, dada a conocer por G. Llabrés, incide en su procedencia menorquina ( $\mathrm{Pa}-$ sarius, 1968, 296). Época alto imperial.

\section{3- Macho cabrío}

Bronce. Hispánic Society of America, inv. D953, originaria de la colección Ramís, y posteriormente en la Vivés. Dimensiones: $3,8 \mathrm{~cm}$ de altura; $6,2 \mathrm{~cm}$ de longitud. Bibliografía: García y Bellido, 1993, 266-267, lám. 296-3; AAVV, 2009, 405, nº 50. Hallada en lugar indeterminado de Menorca, citada en la correspondencia de 1828 de A. Ramis (ver procedencia del carnero anterior). Época alto imperial.

\section{4-Aplique de lámpara en forma de ratón}

Bronce. Paradero desconocido, dimensiones desconocidas. Bibliografía: García y Bellido, 1993, 266-267, lám. 296-5. Procede de Menorca, perteneció a la colección Vives. Época alto imperial.

\section{Manifestaciones iconográficas indeterminadas}

\section{5-Cornucopia perteneciente a una estatuilla de genio o divinidad}

Bronce. Hispánic Society of America, $\mathrm{n}^{\mathrm{o}}$ de inv. D910; dimensiones: $8,2 \mathrm{~cm}$ de longitud. Bibliografía: García y Bellido, 1993, 266-267, lám. 2967. Hallada en Menorca, localización y circunstancias desconocidas. Perteneció a la colección Ramís y posteriormente a la Vives, de donde pasó a la institución norteamericana. Época imperial.

\section{6- Fragmento de brazo de divinidad o personaje mitológico (Fig. 5)}

Mármol blanco. Museo Municipal de Ciutadella, $\mathrm{n}^{\circ}$ de inv. MMC-2472 (col. Sánchez), dimensiones: $5,5 \mathrm{~cm}$ de longitud, $4,7 \mathrm{~cm}$ de anchura. Inédito. Hallazgo fortuito en el yacimiento de Sa Comerma de Sa Garita, en las proximidades del poblado talayótico de Torre d'en Gaumes, aun sin excavar. Época imperial.

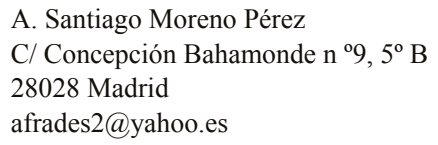

\section{BIBLIOGRAFÍA}

AAVV, 1990: Los Bronces romanos en España, Catálogo de la exposición, Madrid.

AAVV, 1998: La mirada del passat. L'emprenta de les grans civilitzacions de les Illes Balears, Catálogo de la exposición, Palma.

AAVV, 2005: El mundo romano en las Illes Balears, catálogo de la exposición, Barcelona.

AAVV, 2007: Los Etruscos, catálogo de la exposición, Madrid.
AAVV, 2009: El tesoro arqueológico de la Hispanic Society of America, catálogo de la exposición, Sevilla.

ADAMO-MUSCETTOLA, S., 1984: «Observazioni sulla composizione dei larari con statuette in bronzo di Pompei ed Hercolano», Toreutik und Figurliche bronceen romischer zeit, Akten der 6 Tagung uber Antike Bronzen (Berlín, 1980), 9-32, Berlín.

AMENGUAL, J. y ORFILA, M., 2007: «Paganos, judíos y cristianos en las Baleares: documentos literarios y arqueológicos», en J. FERNÁNDEZ y M. MARCOS (Eds.), Libertad e intolerancia religiosa en el Imperio Romano, 'Ilu 18, 197-246, Madrid.

ARASA, F., 2008: «La pequeña escultura en bronce de época imperial en el País Valenciano», en J.M. NOGUERA y E. CONDE (Eds.), Escultura romana en Hispania $V$, Actas de la Reunión Internacional (Murcia 2005), 425456, Murcia.

ARSLAN, A.E. (Ed.), 1997: Iside, Milán.

BARATTA, G. (2001): Il culto di Mercurio nella Penisola Iberica, Instrumenta 9, Barcelona.

BESQUES, S., 1963: Catalogue raisonné des figurines et reliefs en terre-cuite Grecs, Etrusques et romains, II, Myrina, Paris.

BLECH, M. y MARZOLI, D., 1991: «Bronzestatuetten von Mallorca: Mars Balearicus», Madrider Mitteilungen, 32, 94-116.

BOUBE-PICOT, Ch., 1969: Les bronzes antiques du Maroc I, La statuaire, Rabat.

BOUBE-PICOT, Ch., 1975: Bronzes antiques du maroc II. Le Molbilier, Rabat.

BOUBE-PICOT, Ch., 1980: Les bronzes antiques du Maroc III, les chars et l'attelage, Rabat.

BOUCHER, S., 1970: Bronzes grecs, hellenistiques et etrusques du Musee de Lyon, Lyon.

BOUCHER, S., 1974: «Bronzes gallo-romains et bronzes gaulois, problèmes de méthode», Gallia, 32, 1, 137-162.

BOUCHER, S., 1976: Recherches sur les bronzes figurés de Gaule pré-romaine et romaine, Roma.

BRESCIANI, E., 1997: «Statua di Osiride avvolto dalle spire di un serpente», en E. A. AÍSLAN (Ed.), Iside, 231234, Milán.

CAMPBELL, B., 1994: The Roman Army: 31 BC-AD 337. A Source Book, London.

CASESNOVES, M. A., 1988: «Les divinitats importades durant l'época romana a l'Illa de Menorca», Boletín de la Sociedad Arqueológica Luliana, 44, 57-77.

CASSOLA, F., 1981: «Il Templi di Marte Ultore e i Ludi Martiales», Scritti sul mondo antico in memoria di Fulvio Grosso, 99-118, Roma.

CHAMPEAUX, J., 1982: Fortuna: recherches sur le culte de la Fortune à Rome et dans le monde Romain des origines à la mort de Cesar. I. Fortuna dans la religion archaïque, Roma.

CIBal: VENY, C., 1965: Corpus de las inscripciones baleáricas hasta la dominación árabe, Madrid.

CLARKE, J.R., 2007: «Three uses of the pygmy and the aethiops at Pompeii: decorating, othering and warding off demonds», en L. BRICAULT ET ALII (Eds.), Nile into Tiber. Egipt in the roman world, III Int. 
Conference of Isis studies (Leiden 2005), 155-169, Leiden/Boston.

COMBET-FARNOUX, B., 1980: Mercure Romain. Le culte public de Mercure et la fonction mercantile à Rome de la république archaïque à l'époque augustéenne, Roma.

CONTRERAS, F., MÜLLER, R. y VALLE, F.J., 2006: «El asentamiento militar romano de Sanitja (123-45 a.C.): una aproximación a su contexto histórico», Mayurqa, 31, 231-249.

COSTA, J.M., 2011: «Revisando los asentamientos militares en la antigua Galicia ¿centros de producción o de consumo artístico», en T. NOGALES e I. RODÁ (Eds.), Roma y las provincias: modelo y difusión, Actas del XI Coloquio Internacional de Arte Romano Provincial (Mérida 2009), 753-762, Roma.

CRISTOFANI, M., 1985: I bronzi degli etruschi, Novara.

CUMONT, F., 1942: Recherches sur le symbolisme funéraire des romains, Paris.

D'ANDRIA, F., 1970: «I Bronzi romani di Veleia, Parma e del territorio parmense», Contributi dell'Instituto di Archeologia, Serie III, vol. III, 3-141, Milán.

DEL HOYO, J. y VÁZQUEZ HOYS, A.Ma ., 1996: «Clasificación funcional y formal de los amuletos fálicos en Hispania», Espacio, Tiempo y Forma, Serie II-9, 441-466.

DE MIGUEL, M., 2002: «Los honderos baleares: Mercenarios en las filas de las legiones romanas», Arqueología militar romana en Hispania, I Congreso de arqueología militar, 529-535, Madrid.

DE NICOLÁS, J., 1983: «Romanización de Menorca», en J. MASCARÓ PASARIUS (Coord.), Geografía e Historia de Menorca, t. IV, 201-283, Ciutadella.

DE NICOLÁS, J., 1991: «Un testimoni dels Planii, plom de Cartago Nova a 1'Illa de Menorca a finals de la republica romana», Meloussa, 2, 31-48.

DE NICOLÁS, J., 2003: «Els primers segles de l'ocupació romana de 1'Illa de menorca: continuitats i ruptures en 1'ambit rural», Mayurqa, 29, 113-127.

DI STEFANO, C.A., 1975: Bronzetti figurati del Museo Nazionale di Palermo, Roma.

DOMASZEWSKI, A., 1972: Die religión des römischen Heeres, Darmstat.

DOMINGUEZ, A. y AGUILERA, A., 2009: «Caesar Augusta a la luz de los últimos descubrimientos. Consideraciones entorno al aureo de Mars Vltor», Moneda y arqueología, XIII Congreso Nacional de Numismática, 455-472, Cádiz.

DONNAY, G., 1984: «Le Iupitter Tonans du Capitol Romain et ses imitations dans les bronzes figurés», Toreutik und Figürliche Bronzen römischer zeit, Akten der 6 Tagung uber Antike Bronzen, 107-110, Berlín.

EINGARTNER, J., 1991: Isis und ibre die nerinnen in der kunst der römischen kaiserzeit, Leiden.

FERNÁNDEZ DE AVILÉS, A., 1962: «El Hermes de bronce del peralejo (Jaén)», Archivo Español de Arqueología, 35, 158-163.

FERNÁNDEZ-MIRANDA, M., 1976: «La fase final de la prehistoria de Menorca y los primeros contactos comerciales de la isla con el mundo clásico», Revista de Menorca 1976, 5-34.
FERNÁNDEZ-MIRANDA, M., 1981: «Las taulas de Menorca», Revista de Arqueología, 4, 6-13.

FERNÁNDEZ URIEL, P., 1998: «Un aspecto de los lares domésticos. Venus romanas de bronce. Analisis y tipologia», Espacio, Tiempo y Forma, serie II. Historia Antigua, 11, 335-395.

FERNÁNDEZ URIEL, P., BAILÓN, M., y ESPINOSA, T., 2011: «Análisis histórico e iconográfico de Fortuna Dea en los lararios provinciales hispanos», en T. NOGALES e I. RODÁ (Eds.), Roma y las provincias: modelo y difusión, Actas del XI Coloquio Internacional de Arte Romano Provincial, 971-979, Roma.

FINK, R.O., HOEY, A.S. y SNYDER, W.F., 1940: «The Feriale Duranum», Yale Classical Studies, 7, 1-222.

FRANZONI, L., 1973: Bronzetti romani del Museo Archeologico di Verona, Venecia.

FRAPICCINI, N., 1990: «Un bronzetto di Iside-Fortuna da Sentinum», Picvs, 10, 177-19.

FRÖHLICH, T., 1991: Lararien und Fassadenbilder in den vesuvstadten. Untersuchungen zur «volkstümlichen» pompejanischen Malerei, Mainz.

FUCHS, W., 1963: Der Schiffsfrend von Mahdia, Stuttgart.

GALESTIN, M.C., 1987: Etruscan and Italia bronze statuettes, Warfhuizen.

GALliAZZO, V., 1979: Bronzi romani del Museo Civico di Treviso, Roma.

GARCÍA RIAZA, E., 2005: «Ciudades romanas de Baleares: estatutos jurídicos», L'Antiguitat clasica i la seva pervivencia a les Illes Balears, XIII Jornades d'Estudis Historics Locals, 83-99, Palma.

GARCÍA RIAZA, E. y SÁNCHEZ LEÓN, Mª.L., 2000: Roma y la municipalización de las Baleares, Palma.

GARCÍA Y BELLIDO, A., 1948: Hispania Graeca, t. II, Barcelona.

GARCÍA Y BELLIDO, A., 1967: Les religions orientales dans l'Espagne romaine, Leiden.

GARCÍA Y BELLIDO, Mª.P., 1993: Album de dibujos de la colección de bronces antiguos de Antonio Vivés Escudero, Anejos de Archivo Español de Arqueología, 13, Madrid.

GOETTE, H. R., 1990: Studien zu romischen togadarstellungen, Mainz am Rheim.

GORNÉS, J. S., 1997: «Reflexiones en torno al simbolismo tauromorfo en la prehistoria de Menorca», Meloussa, 4, 57-64.

GROS, P., 1976: Aurea Templa. Recherches sur l'Architecture religieuse de Rome à l'époque d'Auguste, Roma.

GUAL, J. M., 1993: Figures de bronze a la protohistòria de Mallorca, Palma.

GUERRERO, V., 1994: «Formación social indígena y relaciones coloniales en la protohistoria balear», Gerión, 12, 155-195.

GURY, F., 1994: «Selene/Luna», Lexicon Iconographicum Mitologiae Classicae VII, 706-715, Zurich und München.

HELGELAND, J., 1978: «Roman Army Religión», Aufstieg und Niedergang der romischen Welt. Geschichte und kultur roms im spiegel der neueren forschung, II, 16.2, 1470-1505, Berlín/New York. 
HERNÁNDEZ SANZ, F., 1908: Compendio de Geografia e Historia de Menorca, Mahón.

JONSON, A., 1983: Roman Forts, Plymouth.

JUAN I BENEJAM, G., 1993: El poblament de Menorca; de la prehistòria a la baixa romanitat, Treballs del $\mathrm{Mu}-$ seu de Menorca 13.

KOLLING, A., 1967: Forschungen im romischen Schearzenacker, I, Die Bronzestatuetten aus dem Saülenkeller, Schwarzenacker.

KUNCKEL, I., 1974: Die Römische Genius, Heildelberg.

LE BOHEC, Y., 1994: The Imperial Roman Army, Londres.

LLOMPART, G., 1960: «Mars Balearicus», Boletín del Seminario de Arte y Arqueología, 25, 101-128.

LLOMPART, G., 1970: «La religión del hombre prehistórico en Mallorca», en J. MASCARÓ PASARIUS (Coord.), Historia de Mallorca, vol. 1, 225-269, Palma.

MARTÍN, M., 2009: «Colgante con representación de genitales masculinos», en A.M. POVEDA y F.J. NAVARRO (Eds.), Sexo y Erotismo: Roma en Hispania, catálogo de la exposición, 183, Murcia.

MASCARÓ PASARIUS, J.M., 1968: «Las taulas. Testimonio de la fe religiosa y la capacidad creadora de los paleo-menorquines», Revista de Menorca, 1968, 213-330.

MAYER, M., 1996: «Aproximación sumaria a la epigrafía rupestre e hipogea de la Hispania Citerior», Saxa Scripta, Actas del simposio internacional ibero itálico sobre epigrafía rupestre, 35-46, La Coruña.

MÉLIDA, J.R., 1900: «La colección de bronces antiguos de D. Antonio Vives», Revista de Archivos, Bibliotecas y Museos, t. IV, 404-409.

MONTANDON, B., 1997: «Le travail du bronze à l'époque gallo-romaine», Chronozones, 3, 2-11.

MORENO DE PABLOS, Ma. J., 2001: La religión del ejercito romano: Hispania en los siglos I-III, Madrid.

NIKOLOSKA, A., 2011: «The iconography of Magna Mater on the monuments from the Republic of Croatia», en T. NOGALES e I. RODÁ (Eds.), Roma y las provincias: modelo y difusión, Actas del XI Coloquio Internacional de Arte Romano Provincial, vol. I, 385-394, Roma.

NOGUERA, J. M., 2003: «La escultura hispanoromana en piedra de época republicana», en L. ABAD (Ed.), De Iberia in Hispania. La adaptación de las sociedades ibéricas a los modelos romanos (Soria, 2001), 153-208, Alicante.

OGGIANO-BITAR, M., 1994: «Tipologíe de Mercure en Gaule», Akten der X Int. Tagung ubre Antike Bronzen, 311-318, Stuttgart.

ORFILA, M., 1982-83: «Estatuillas de bronce antiguas», en J. MASCARÓ PASARIUS (Coord.), Geografía e Historia de Menorca, tomo IV, Ciutadella, fasc. 47, 85-128; fasc. 48, 97-128; Fasc. 49, 129-147.

ORFILA, M., 1995: «Arqueología romana», Enciclopedia de Menorca, t. VIII, Arqueología, Ciutadella, 195-264.

ORFILA, M., 2008: «La intervención de Q. Cecilio Metelo sobre las Baleares (123 a 121 a.C.). Condiciones previas y sus consecuencias», Pyrenae, 39, vol. 2, 7-45.

ORFILA, M. y SINTÉS, G., 1980-1984: «Estudio preliminar sobre la perduración del hábitat en los conjuntos talayóticos menorquines», Mayurqa, 20, 19-46.
ORFILA, M., ARRIBAS, A. y CAU, M.A., 1999: «El foro romano de Pollentia», Archivo Español de Arqueología, 72, 99-118.

ORFILA, M. y RIERA, M., 2004: «Les ciutats romanes de Menorca», en M. ORFILA y M.A. CAU (Eds.), Les ciutats romanes del Llevant peninsular i les Illes Balears, 239-260, Barcelona.

ORFILA, M., CHÁVEZ, M.E. y CAU, M.A., 2006: «Pollentia and the cities of the Balearic Islands», en L. ABAD, S. KEAY y S. RAMALLO (Eds.), Early Roman Towns in Hispania Tarraconensis, 133-145, Oxford.

ORFILA, M., BARATTA, J. y MAYER, M., 2010: «Los santuarios de Cales Coves (Alaior, Mallorca): Coberxo Blanc y Cova del Jurats o de 1'Esglesia. Informe preliminar», Cuadernos de Prehistoria y Arqueología de la Universidad de Granada, 20, 439-477.

PALAGIA, O., 1988: «Herakles», Lexicon Iconographicum Mitologiae Classicae IV, 728-838, Zurich und München.

PENA, Ma. J., 2005: «Grafitos del Santuario de So n'Oms: nuevos datos para el estudio de la romanización de Mallorca», Revista de Estudios Latinos, 5, 205-224.

PLANTALAMOR, L., 1991: L'arquitectura prehistòrica $i$ protohistòrica de Menorca i el seu marc cultural, Treballs del Museu de Menorca, 12.

PONS, O., 2005: «Desenvolupament de l'excavació i studi dels materials», en G. JUAN I BENEJAM y J. PONS (Coords.), Talati de Dalt 1997-2001. 5 anys d'investigació a un jaciment talaiotic tipus de Menorca, Treballs del Museu de Menorca, 29, 25-133.

POZO, S. 1989: «Bronces romanos de Pollentia conservados en el M.A.N. de Madrid». Boletín del M.A.N., tomo VII (n' 1 y 2), 67-85.

PRIEUR, J., 1991: La morte nell'antica Roma, Génova.

RAMIS, A., 1833: Inscripciones relativas a Menorca y noticia de varios monumentos descubiertos en ella, Mahón.

RAUSA, F., 1997: «Fortuna», Lexicon Iconographicum Mitologiae Classicae VIII, 127-128, Zurich und Dusseldorf.

RITA, C., 2007: «Menorca romana: les fonts escrites i la documentació arqueològica», Revista de Menorca, 90 (1), 115-151.

RITA, C., LATORRE, J. L. y ORFILA, J. A., 1984: «Las excavaciones arqueológicas en el yacimiento de Sanitja (Menorca) hasta 1984», Les Illes Balears en temps cristians fins als arabs, 41-49, Maó.

RITA, C. y PLANTALAMOR, L., 1988: «Informe de las excavaciones de urgencia en la calle Alfonso III de Maó», Meloussa, 1, 167-170.

RODÁ, I., 1990: «Bronces romanos de la Hispania Citerior», AAVV 1990, 71-90.

ROULLET, A., 1972: The egyptian and egyptiazing monuments of imperial Rome, Leiden.

ROUSSEL, E., 1979: «Les artisans bronziers de MalainMediolanum», Bronzes hellenistiques et romains. Tradition et renouveau, Actes $\mathrm{V}^{\circ}$ Colloque Inter. sur les bronzes antiques, 215-221, Lausanne.

RUGGIERO, I., 1997: I luogui di culti, Vita e costumi dei romani antichi 20, Roma.

SBORGI, F., 1995: «La escultura en metal», en C. MALTESE (Coord.), Las técnicas artísticas, 41-67, Madrid. 
SENA, G. y FACHINI, G.M., 1985: «Gemme romane di eta imperiale: produzione, comerci, committenze», Aufstieg und Niedergang der romischen Welt. Geschichte und kultur roms im spiegel der neueren forschun II,12,3., 3-31, Berlín-New York.

SERRA, Ma . L., ROSELLÓ, G., ORFILA, J.A. y DE NICOLÁS, J.C., 1977: Historia de Menorca, tomo I, de los origenes al final de la edad media, Mahón.

SIMON, E., 1984: «Ares/Mars II. Römische Denkmäler von der mittleren republik bis zur spatantike», Lexicon Iconographicum Mitologiae Classicae II, 511-559, Zurich und München.

SIMON, E., 1997: «Kybele», Lexicon Iconographicum Mitologiae Classicae VIII, 744-766, Zurich und Dusseldorf.

SINTÉS, E. e ISBERT, F., 2008: Investigación arqueológica y puesta en valor del recinto Cartailhac, Ministerio de Cultura, mcu.es/patrimonio/Duch/MC/IPHE/Patrimonio CulturalE/N1/19.
SÖLDNER, M., 1986: Untersuchungen zu liegenden Eroten ib der hellenistischer und römische Kunst, Berlín.

TRAM TAN THIN, V., 1984: «État des études iconographiques relatives à Isis, Serapis et Sunnaoi Theoi», Aufstieg und Niedergang der romischen Welt. Geschichte und kultur roms im spiegel der neueren forschung, II, 17.3, 1710-1738, Berlín/New York.

TRAM TAN THIN, V., 1990: «Isis», Lexicon Iconographicum Mitologiae Clasicae V, 761-796, Zurich und München.

TRILLMICH, W., 1990: «Apuntes sobre algunos retratos de bronce de la Hispania romana», AAVV 1990, 37-50.

TURCAN, R., 1989: Les cultes orientaux dans le monde Romaní, París.

VÁZQUEZ HOYS, A.Mª 2009: «Los amuletos o talismanes fálicos en Hispania», en A.M. POVEDA y F.J. NAVARRO (Eds.), Sexo y Erotismo: Roma en Hispania, catálogo de la exposición, 42-67, Murcia.

ZUCCA, R., 1998: Insulae Baliares. Le isole Baleari sotto dominio romano, Roma. 